\title{
Türkiye'de Yaşayan Suriyeli Çocuklar ve Aileleri: Anlatılmayan Karşıt Hikâyeler
}

\author{
Elif KARSLI ÇALAMAK* \\ Ersoy ERDEMIR**
}

\begin{abstract}
Öz: Bu araştırma, Türkiye'de yaşamaya başlamış Suriyeli mülteci aile ve çocukların Erken Çocukluk Eğitimi (EÇE) ekseninde edindikleri deneyimlerini yansıtan sık duyulmayan karşıt hikâyeleri, Kurgulanmış Dünyalar kuramına göre incelemiştir. Araştırma kapsamında, Ankara, Gaziantep, Mardin, Hatay, İstanbul ve Şanlıurfa kentlerinde yaşayan mülteci aile ve çocuklardan toplanan veriler; bu aile ve çocukların EÇE hizmetlerine erişim ve katılım deneyimlerini aktaran karşıt hikâyeler veri setini oluşturmuştur. Hikâye analizi yöntemi kullanılarak toplam 32 hikâye sistematik bir şekilde derinlemesine analiz edilmiştir. Araştırma bulguları aile ve çocukların eğitime ilişkin eylemlilikleri, bir diğer deyişle, mücadele etme, iyileşme, yetkinliklerini sergileme, kaynak arama ve kaynak yaratma deneyimlerine işaret etmektedir. Bu bulgular, aile ve çocukların kendileri ve birbirleri için çeşitli dünyalar kurgulayarak, basmakalıp mülteci kimliğinin ötesinde, geçmişten getirdikleri ve Türkiye'de yeni bir yaşam inşa etme sürecinde edindikleri çoklu kimliklerinin güçlü yönlerini ortaya koymaktadır. Araştırma bulguları doğrultusunda, mülteci bireylerin deneyimlerini ele alan eğitim araştırmalarına ve ülkedeki yüksek mülteci çocuk nüfusu düşünülerek, öğretmen eğitimine dair öneriler paylaşılmaktadır.
\end{abstract}

Anahtar Sözcükler: Karşıt Hikâyeler, Anlatılmayan Hikâyeler, Erken Çocukluk Eğitimi, Suriyeli Mülteciler, Mülteci Çocuklar, Mülteci Aileler

\section{Syrian Children and Families in Turkey: Missing Stories and Counter Narratives}

\begin{abstract}
Drawing on the Figured Worlds theory, this study investigates the counter narratives of Syrian refugee families and children living in Turkey as reflective of their experiences in accessing and participating in early childhood education services. Agents of these stories were refugees living in the cities of Ankara, Gaziantep, Mardin, Hatay, İstanbul and Şanlıurfa. Utilizing narrative analysis method, 32 counter narratives were analyzed systematically in an in-depth fashion. Findings revealed the agency of families and children, in particular, their practices of coping, recovery, resilience, and competence along with searching for and creating educational resources. Beyond the conventional and stereotypical perceptions of refugee identity, findings also show that refugee children and families figure out multiple identities, which are either carried from the past or constructed at the present as they build a new life in Turkey. This process of figuring out multiple identities were enacted while families and children figure out identities in relation to both themselves and other actors in their lives. The study has implications for educational research and teacher education in Turkey as the country hosts the world's largest number of child refugee population in the world.
\end{abstract}

Keywords: Counter Narratives, Missing Stories, Early Childhood Education, Syrian Refugees, Refugee Children, Refugee Families

* University of South Carolina, Faculty of Education, Early Childhood Education Department, Columbia, USA, e-posta: karsli@mailbox.sc.edu, ORCID: https://orcid.org/0000-0001-7280-994X

** Boğaziçi Üniversitesi, Eğitim Fakültesi, Erken Çocukluk Eğitimi, İstanbul, Türkiye, e-posta: ersoy.erdemir@boun.edu.tr, ORCID: https://orcid.org/0000-0002-8458-0422 
Bu araştırmanın amacı Türkiye' de yaşayan Suriyeli aileler ve çocukların Erken Çocukluk Eğitimine (EÇE) dahil olma sürecindeki deneyimlerini keşfederek, bu deneyimlerini açığa çıkaran, sık duyulmayan ve tanık olunmayan hikâyelerini Kurgulanmış Dünyalar (Figured Worlds) kuramına (Holland, Lachicotte, Skinner, ve Cain, 1998) göre incelemektir. Araştırma, Suriyeli çocuklar ve ailelerinin güçlü özelliklerine, yetkinliklerine, eylemliliklerine (agency) böylece olumlu yönlerine odaklanan karşıt hikâyeler (counter narratives) ve bu hikâyelere işlenmiş yaşantılar üzerinden kurgulanmış dünyalarını çok yönlü bir açıdan keşfetmekte, irdelemekte ve aktarmaktadır. Ayrıca, bu araştırma sosyal adalet adanmışlığından hareketle Suriyeli aileler ve çocukların güçlü yönlerini ve olumlu deneyimlerini vurgulayan karşıt hikâyelerin duyulur kılınması, eğitimciler tarafından benimsenip yaygınlaştırılması ve bu tür başka karşıt hikâyelerin keşfedilip ortaya çıkarılmasını hedeflemektedir.

Birleşmiş Milletler Mülteciler Yüksek Komiserliği (BMMYK, 2019) verilerine göre yaklaşık 4 milyon Suriyeli ile Türkiye, dünyanın en büyük mülteci nüfusuna ev sahipliği yapan ülke konumundadır. 2011 senesinde Suriye'deki iç çatışmalar sonucu başlayan yoğun kitlesel göç, dünya tarihinin en büyük mülteci hareketi olarak nitelendirilmektedir. Yaklaşık 5,7 milyon Suriyeli birey komşu ülkelere ve Avrupa ülkelerine sığınmacı olarak göç etmek durumunda kalmıştır (BMMYK, 2019). Rakamsal boyutları itibariyle, yaşanan bu durum yakın tarihte görülen en büyük kitlesel göç dalgası olarak nitelendirilmektedir (Erdoğan, 2016).

Göç İdaresi Genel Müdürlüğü (GİGM) tarafından yayınlanan Mart 2019 verilerine göre 3.651 .635 milyon Suriyeli birey geçici koruma kapsamı altında Türkiye'de yaşamaktadır (GIGM, 2019)1. İnsan Hakları İzleme Örgütü' (2015), kitlesel göçten etkilenen milyonlarca Suriyeli çocuğun ve gencin; ailenin sosyoekonomik düzeyi, kaynak arayışları, dil ve kültürel farklılıklar gibi sebeplerden ötürü göç ettikleri ülkelerde gelişimlerini ve eğitim süreçlerini destekleyecek hizmetlere erişimlerinin kısıtlı olduğunu ve bu durumun bir nesli tehlike altına aldığını belirtmiştir. Bu sebeple Suriyeli mültecilerin yoğun olarak göç ettiği ülkelerde ulusal müdahale stratejilerinin geliştirilmesi ve eğitim ve sosyal destek hizmetlerinden faydalanmaları adına geniş bir hak yelpazesine erişimlerinin sağlanması, mülteci bireylerin göç ülkesinde destekleyici ve olumlu yaşam deneyimleri ile hayatlarını sürdürmeleri adına önem kazanmaktadır. Bu sebeple, Suriyeli ailelerin ve çocukların eğitim ve sosyal yaşantılarına ilişkin (karşıt) hikâyelerin derlenmesi, kuramsal bir bakış açısı ışığında derinlemesine irdelenmesi ve ilgili mecralarla paylaşılmasının, mülteci bireylerinin yaşam deneyimlerinin bütüncül şekilde anlaşılmasına ışık tutacağı düşünülmektedir.

Bu bağlamda, bu çalışmanın temel araştırma sorusu şu şekilde belirlenmiştir: Türkiye'de yaşayan Suriyeli aileler ve çocukların erken çocukluk eğitimi hizmetlerine erişim deneyimlerine ilişkin anlatılmayan ve sık duyulmayan (karşıt) hikâyeler nelerdir ve bu hikâyeler aileler ve çocukların kurgulanmış dünyalarına dair neler ifade etmektedir?

\section{Türkiye'de Suriyeli Çocuklar ve Erken Çocukluk Eğitim Hizmetlerine Erişim}

Türkiye'de yaşları 0 ile 9 arasında olan yaklaşık bir milyonun üzerinde Suriyeli çocuğun olduğu belirtilmektedir. Mart 2019 verilerine göre, geçici koruma kapsamı altında olan 0-4 yaş arası Suriyeli çocukların sayısı 502.056 iken 5-9 yaş arası çocukların sayısı 504.582'dir (GİGM, 2019). Kitlesel göçün ilk yıllarında kurulan "Geçici Eğitim Merkezleri” (GEM) ile geçici koruma statüsüne sahip çocukların Suriye müfredatına göre Arapça dilinde eğitim alması desteklenmiştir. Nisan 2013'den itibaren Suriyeli fertlerin sağlık ve diğer temel hizmetlere olduğu gibi eğitime erişim hakları da resmi olarak tanımlanmıştır. Bununla beraber, Ağustos 2016'da eğitim çağındaki Suriyeli çocuk nüfusunun kademeli olarak MEB'e bağlı resmi okullara kaydedileceği, böylece GEM’lerin kapatılarak 2019 yılında sonlandırılacağı duyurulmuştur.

Suriyeli çocukların MEB'e bağlı resmî okullara kaydedilmesine ilişkin çalışmalar devam etmektedir ve GEM'lerin kademeli olarak kapatılmasıyla okullaşma oranının yükseldiği görülmektedir. 2019 yılı itibariyle yaklaşık bir milyon okul çağındaki Suriyeli çocuğun 480.000'i devlet okullarında eğitim almaktadır. Bu

1 Türkiye'de yaşayan Suriyeli bireylerin statüsü resmi olarak "geçici koruma kapsamı” çerçevesinde tanımlanmaktadır. Bu makalede "mülteci" kelimesi kullanılmış ve bu kullanım bireylerin mülteci kimliğini önceliklendirmekten ziyade, bireylerin zorunlu göçe ilişkin ortak deneyimini ifade etmek amacıyla kullanılmıştır. 
doğrultuda Hayat Boyu Öğrenme Genel Müdürlüğü Göç ve Acil Durum Eğitim Daire Başkanlığı mart ayı verilerine göre (MEB, 2019) çağ nüfusu toplamı 95.904 olan 5-6 yaş grubu çocuklardan, anasınıflarına kayıtlı olanların oranı bu nüfusunun yaklaşık \%33'ünü oluşturmaktadır. Erken çocukluk yıllarının 0 ila 5 yaş arasını kapsayan döneminde olup kreş veya bakım evi gibi herhangi bir kurum temelli okul öncesi hizmetinden yararlanan çocukların verisine ise ulaşılamamaktadır. Okullaşmanın en yoğun olduğu eğitim kademesi ilkokul (\%96,57), en az olduğu eğitim kademesi ise lise (\%26,69) ve 5-6 yaş grubunu oluşturan ana okullarıdır (\%33,76). Suriyeli okul öncesi dönemdeki çocukların EÇE hizmetlerine erişiminin oldukça kısıtlı olduğunu gösteren bu durum okul öncesinde okullaşma oranının yükseltilmesi gerektiğine işaret etmektedir (ERG, 2019). 2018 yılında MEB tarafından yayınlanan 2023 Eğitim Vizyonu belgesine göre 5 yaşın erken çocukluk eğitiminde 2023 yılından itibaren zorunlu eğitim kapsamına alınacağı duyurulmuştur (MEB, 2018). Bu çerçevede Suriyeli çocukların EÇE hizmetlerine erişiminin artacağ

MEB bazında Suriyeli çocukların okul deneyimlerinin iyileştirilmesi ve Türkçe dil yetkinliklerinin desteklenmesini hedefleyen geniş çaplı projelerden biri Ekim 2016'da başlatılan Suriyeli Çocukların Türk Ĕ̆itim Sistemine Entegrasyonunun Desteklenmesi Projesi (PICTES)'dir. Bununla birlikte MEB'in, sinıfında Suriyeli öğrencisi olan öğretmenlere mesleki gelişim eğitimleri sağladığ

MEB tarafından yasal yürürlüklerle sağlanan eğitim hizmetlerin yanı sıra, Suriyeli çocuklar, gençler ve aileler için çeşitli bakanlıklar ve Sivil Toplum Kuruluşları (STK) tarafından projeler uygulanmakta ve hedef kitle sosyal, kültürel ve ekonomik yönlerden desteklenmeye çalışılmaktadır. Örneğin, Aile, Çalışma ve Sosyal Hizmetler Bakanlığı tarafından istihdam desteği projeleri, Gençlik ve Spor Bakanlığı tarafından sanatsal, sportif ve mesleki eğitim projeleri, Sanayi ve Teknoloji Bakanlığı tarafından sosyal istikrar, iş fırsatları geliştirme, mülteci kadınlara yönelik ekonomik güçlenme projeleri gerçekleştirilmektedir. Ayrıca, özellikle çocuk, genç ve kadınların desteklenmesine yönelik faaliyet gösteren UNICEF, Anne Çocuk Eğitim Vakfı, Yuva Derneği, Kadın Emeğini Değerlendirme Vakfı, Hayata Destek gibi ulusal ve uluslararası sivil toplum kuruluşları da beraber yaşam, kadın güçlenmesi, istihdam, eğitim, kültür sanat ve spor faaliyetleri alanında Suriyeli nüfusa hizmet götürmektedir. EÇE alanında hızlandırılmış yaz anaokulları projeleri, ev temelli eğitim uygulamaları, okul öncesi dönemde çocukları olan Suriyeli anneler için anne destek programları, kadın kooperatifleri ve çocukların erişimi için gezici/mobil kütüphaneler gibi birçok eğitim ve sosyal hizmet proje faaliyeti gerçekleştirilmektedir.

Suriyeli aileler ve çocukların proje faaliyetleri ve/veya yasal yürürlükler aracılığıyla edindikleri eğitim hizmetleri ve ilgili sosyal kaynaklara erişim deneyimlerinde oluşan hikâyelerin keşfedilmesi, irdelenmesi ve aktarılması; göç ülkesindeki yaşantılarının bu kitlenin kurgulanmış dünyalarına göre nasıl ve ne şekillerde gerçekleştiğini anlamak adına önemlidir. Bu çalışma da aileler ve çocukların güçlü yönlerini, yetkinliklerini ve yapıcı eylemliliklerini yansıtan karşıt hikâyeler aracılığıyla Suriyeli fertlerin deneyimlerini kurgulanmış dünyalar kuramı çerçevesinde inceleyerek bu hikâyelere ses vermektedir.

\section{Alanyazında Mülteci Statüsünde Bulunan Çocuklar ve Ailelerin Eğitime Katılımı}

Yukarıda belirtilen araştırma amacı doğrultusunda, ilgili alanyazın, mülteci statüsünde bulunan çocukların ve ailelerin eğitime yönelik yaşam deneyimlerini bütüncül şekilde ve önyargı barındıran varsayımları sorgulayarak gerçekleştirilmiş bilimsel çalı̧̧malar kapsamında ele alınmıştır. Tarihsel olarak incelendiğinde, pek çok araştırma, içinde bulunduğu toplumun yaygın yapısından kültür, dil ve bireysel özellikleri ile farklılaşan çocukların eğitime erişimlerinde ve sonrasında başarı göstermede zorluklar ile karşılaştıklarını; ailelerinin ise çocuklarının eğitimine dahil olmaları ve okula katılımları konusunda sıkıntılar yaşadıklarını göstermektedir (Delgado-Gaitan, 1991; Lawrence-Lightfoot, 1978). Halbuki her çocuk uygun koşullar içerisinde, diğer bir deyişle, ihtiyaçlarının gözetildiği, güvende hissettiği, kültürü ve aile geçmişi anlamında değer gördüğü, gerçek yaşam deneyimlerinin yansıtıldığı eğitim ortamlarında başarı gösterebilir (Bekman, 1998). Aileler ise, yaşam koşulları elverdiği ve şekillendirdiği üzere çocuklarının iyiliği ve eğitimi için kendilerine özgü olan ve anlamlı gördükleri şekillerde çocuklarının eğitim süreçlerine dahil olurlar (Allexsaht-Snider, 2006; Hong, 2011; Gonzales, Moll ve Amanti, 2005). Çocuğun akademik başarı ölçütleri ve ailenin çocuğun eğitimine etkili katılım gösterme biçimleri, tek yönlü olarak okul tarafından tanımlandığında 
Türkiye'de Yaşayan Suriyeli Çocuklar...

ya da aile ve çocuğun ihtiyaçlarına göre şekillendirilmediğinde, bu tanımlara uymayan çocuklar başarısız, bu tanımlara uymayan aileler ise çocuklarının eğitimi konusunda ilgisiz olarak konumlanabilir (CalabarseBarton, Drake, Perez, St. Louis ve George, 2004; Lareau, 2003). Bu durumlarda, çocukların okul dışı becerileri ve ailelerin okul ortamı dışında çocukları için verdikleri emekler görünmez olur (Dantas ve Manyak, 2010; Gonzales, Moll ve Amanti, 2005). Anlatılmayan karşıt hikâyelerin incelendiği bu çalışmaya, bu eleştirel bakış açısını temel alan çalışmalar ışık tutmuştur.

Mülteci ailelerin göç ile değişen yaşam koşulları ile birlikte, çocuklarının iyiliğini ve eğitimlerini ne şekillerde desteklediklerini ortaya koyan araştırmalar oldukça sınırlıdır. Bu konuda yapılan çalışmaların pek çoğunun mülteci ailelerden ziyade göçmen ailelere ya da azınlık statüsündeki ailelere odaklandığı görülmektedir (Georgis, Gokiert, Ford ve Ali, 2014). Halbuki zorunlu göç ve getirdiği psikolojik zorluklar (Özer, Şirin ve Oppedal, 2013) mültecilik statüsü (Beiser, 2009) ve geleceğe dair belirsizlik gibi durumlar (Turney ve Kao, 2009) mülteci ailelerin çocuklarının eğitimi için verdikleri çabaları farklılaştırır. Türkiye'de yapılan çalışmalar, mülteci ailelerin yaşam koşulları zor olmasına rağmen kamp içinde (El-Khani, Ulph, Peters ve Calam, 2018a) ve kamp dişında (Çelik ve İçduygu, 2018; Erdemir, 2017a; Erdemir, Diri, Büyükabacı ve Kaya, 2018; Karslı-Çalamak, 2018) çocuklarının eğitim olanaklarından faydalanmaları için fırsatlar aradıklarını ve gerektiğinde bizzat inisiyatif alarak olanaklar yarattıklarını göstermektedir. Bu süreçte ekonomik zorluklar, kardeş sayısının yüksekliği, ailenin eğitim durumu (Uyan-Semerci ve Erdoğan, 2018) ve okul ortamında ana dilde eğitim-öğretim yapılamamasının (Erdemir, 2017b; Karan ve Erdemir, 2019; Karsl1Çalamak, Tuna ve Allexsaht-Snider, 2019) mülteci çocukların eğitime erişimini zorlaştırıcı faktörler olduğu saptanmıştır. Uluslararası alanyazında ise, mülteci ailelerin güçlü yönlerine odaklanan önleyici müdahale programlarının aile ve çocuklar için verimli sonuçlar yarattığı ifade edilmektedir (Critelli, 2015; Dybdahl, 2001; Ingleby ve Watters, 2002; Morrison, Pikhart ve Goldblatt, 2017).

İçinde yaşadığı toplumun yaygın kültüründen farklı bir kültüre sahip, bir diğer deyişle, toplumun periferinde konumlanan ailelerin, çocuklarının eğitimine katılımını inceleyen çalışmalar arasında, son yıllarda özellikle göçmen kadınların anne kimlikleri ile birlikte eylem ve çabalarını inceleyen çalışmaların olduğu göze çarpmaktadır. Bu çalışmalar, okulların daha çok orta sınıf ailelere hitap eden kurumlar olmasını tenkit eder ve okulların öngördügü aile katılımı uygulamalarına ancak toplumun baskın kültürel yapısından gelen orta sınıf ailelerin sahip olduğu materyal ve kültürel kapitaller sayesinde dahil olunabildiğini gösterir (Calabarse ve diğerleri, 2004; Lareau, 2003). Bu sistemde, orta sınıf getirilerinden mahrum olan ailelerin, özellikle kadınların, çocukları için verdikleri emekler görünmez, fark edilmez ya da değer verilmez olur. Halbuki, feminizm odaklı kuramları rehber alan pek çok çalışma göstermektedir ki, göçmen anneler okul dışında çocuklarını desteklemek için önemli kadın dayanışması faaliyetleri gerçekleştirmektedirler (Collins, 1994; Valdes, 1996). Bunun yanı sıra, çocuklarına hikâyeler anlatarak, kendi geçmiş deneyimlerini aktararak (Delgado-Gaitan, 2005; Kayumova, Karsl1, Allexsaht-Snider ve Buxton, 2015; Villenas, 2005), yaşama dair gerçekçi gözlemlerini, yüksek umutlarını paylaşarak ve kaynaklar arayıp yaratarak (Durand, 2011; Elenes, Gonzalez, Delgado-Bernal ve Villenas, 2001; Erdemir, 2017b; Kayumova ve diğerleri, 2015) çocuklarının hem mevcut eğitimine katkı sağlamakta hem de ilerisi için kariyer hedefi belirlemelerine destek olmaktadırlar (Karsl1-Çalamak, 2018; Yosso, 2006). Ailelerin bu tür eylemlerini görmemize olanak sağlayan çalışmalara alanyazında halen ihtiyaç vardır.

Mülteci ailelerin göç ile değişen yaşam koşulları içinde çocuklarının eğitimlerini ne şekillerde desteklediklerini ortaya koyan çalışmalar sınırlı olduğu gibi, mülteci çocukları merkeze alan ve çocukların eğitim deneyimlerini; çocuk ve/veya yakın çevresi gözünden inceleyen çalışmaların da sınırlı olduğu görülmektedir. Eğitim alanyazınında var olan sınırlı sayıdaki bu çalışmaların çoğunluğunda ise yoğun olarak mülteci çocukların travmaları, ihtiyaçlarını karşılayamamaları, akademik başarılarının düşüklüğü, zayıf sosyal-duygusal becerileri gibi olumsuz deneyimlere odaklanarak bu çocukların başarı hikâyelerinin göz ardı edildiği; böylece yetersiz, eksik ve örselenebilir bir kitle olduklarına ilişkin yanlış bir algının yaygınlaştığı dile getirilmektedir (Baker ve McEnery, 2005; Strekalova-Hughes, Nash ve Erdemir, 2017; Wang, StrekalovaHughes ve Cho, 2019). Mülteci çocukları genellikle göç edilen ülkenin yerel çocukları ile karşılaştırma 
dikotomisi ve medyanın mülteci çocukların deneyimlerinin olumlu ve güçlü yönlerini resmetmemesi, bu yetersizlik, eksiklik ve örsenebilirlik algısını pekiştirmektedir (Sampson, 2016; Tyeklar, 2016). Ekolojik sistemler kuramına göre (Brofenbrenner, 1979) bu minvalde algıların oluşmasına, toplumda çocuğu çevreleyen katmanlı sistemlerdeki algılar, bireyler, ilişkiler, politikalar, kurumlar ve bunların yarattı̆̆ı lokomotif etkilere neden olmaktadır. Örneğin, medyanın idame ettirdiği, mülteci statüsündeki bireylerin kültürel farklılıklarına ilişkin algı ve tanımlamalar, politik söylem ve aksiyonlar, hukuk, eğitim ve sağlık sistemlerinin mülteciler için uygulamaya geçirilmesi noktasında yaşanan aksaklıklar bahsi geçen olumsuz ve yanlış algıları şekillendirebilmektedir. Süregelen bu olumsuz algı ve tek yönlü anlatıların ötesine geçmek adına araştırmacılar son yıllarda mülteci çocukların yetkinliklerine, başarılarına, güçlü yönlerine ve dayanıklılıklarına dair anlatılmayan hikâyeleri ortaya çıkarmanın önemini vurgulamaktadır (Ryu ve Tuvilla, 2018; Strekalova-Hughes, Nash ve Erdemir, 2018; Wang ve diğerleri, 2019). Bu tür çalışmalar ulusal alanyazından ziyade uluslararası alanyazında karşımıza çıkmakla birlikte, sayıları halen sınırlıdır.

Bu çalışmalardan bazıları kamplarda yaşayan mülteci çocukların geleceğe dair planları ve beklentilerine ilişkin zorlayıcı koşullara rağmen sergiledikleri direnç ve yetkinliklerini (Bknz: Arvanitis, Yelland ve Kiprianos, 2019) ve hikâye anlatıcılığı pratiğiyle kültürel ve dilsel miraslarını göç ülkesindeki okul toplumlarına entegre ettiklerini göstermektedir (Bknz: Strekalova-Hughes ve Wang, 2019). İlgili diğer çalışmalar, çocukların sosyal-duygusal "eksiklikleri" yerine "güçlü yönlerine" yoğunlaşan öğretmenlerin, uygun öğretim yöntemleri ve müfredat ile çocukların başarılarını desteklediğini (Bknz: Cho, Wang ve Christ, 2019) ve mülteci çocukların, dergi ve şiir yazım atölyeleri aracılığıyla, göç öncesi ve sonrası deneyimlerini geleceğe dair hedef ve hayallerine bilinçli şekillerde entegre edebildiklerini ortaya koymaktadır (Bknz: Daniel, 2019). Bununla birlikte, diğer araştırmalar, okul-aile iş birliği sonucu mülteci çocukların kültürel değerlerinin okul deneyimlerini dönüştürmesi (Bknz: Kroeger, Mariyam ve McTeer, 2019) ve yerel sivil toplum programlarına, sosyal ağlarını genişletmek için katılan genç mültecilerin "öteki ve mağdur" bir kimlikten "güçlü ve sosyal açıdan yetkin" bir kimliğe bürünme süreci gibi konulara odaklanmaktadır (Bknz: Kolano ve Davilla, 2019).

Eleştirel bakış açısıyla incelenen bu çalışmalar, mülteci çocukların ve ailelerin kendileriyle özdeşleştirilen "mağdur", "eksik", "yetersiz", "örselenebilir", "ilgisiz" gibi çağrışımların ötesinde, destekleyici fırsatlar sunulduğunda ya da aile ve çocukların az bilinen çaba ve pratiklerine odaklanıldığında, güçlü yanlarını, yetkinlik ve potansiyellerini yansıtan hikâyeleri görülür kılmaktadır. Yapılan bu araştırmanın da bahsi geçen ilgili alanyazına ulusal boyutta katkı sağlayacağı düşünülmektedir.

\section{Kuramsal Bakış Açısı: Kurgulanmış Dünyalar}

İçinde bulunduğu toplumun baskın kültürel yapısından dil, din, etnik köken ve inanç gibi özellikleri ile farklılaşan toplulukların, birey ve topluluk bazında yaşam ve eğitim deneyimlerini anlamlandırma sürecine, eleştirel ırk kuramı (Ladson-Billings ve Tate, 1995), kültürel kimlik kuramları (Cote ve Levine, 2002), kültürel bilgi fonu kuramı (Gonzales, Moll ve Amanti, 2005), ve kültürel-tarihsel kuram (Leontiev, 1978; Vygotsky, 1978) uzun yıllardır rehberlik etmiştir. Bununla birlikte, baskın kültürden farklı kültürel değer ve pratiklere sahip birbirinden değişik grupların bağdaşık bir topluluk olamayacağı göz önünde bulundurulduğunda, mülteci statüsünde bulunan çocuklar ve ailelerin yaşam deneyimlerini, özellikle eğitime ilişkin yaşantılarını anlama ve yorumlamaya olanak sağlayacak ayırt edici nitelikleri olan kuramların ilgili alanyazında eksikliği fark edilmektedir. Mülteci statüsünde bulunan çocuk ve aileler göç toplumunun bireyleri tarafından fark edilmesi gereken ayırt edici yaşam deneyimlerine sahiptir. Zira mülteciler, kültürel farklılıklarının yanında vatandaşı oldukları ülkelerdeki temel yaşam ve insan haklarını tehdit eden olumsuz deneyimleri sonucunda zorunlu göçe maruz kalmakta ve ikamet ettikleri ya da gitmeyi hedefledikleri ülkelerde geleceklerine dair birçok belirsizlikle karşılaşmaktadırlar. Mültecilik statüsünün getirdiği bu ortak deneyimler ile birlikte de bu statüyü taşıyan bireylerin kendi kişisel hikâyeleri ve deneyimlerinin olduğu da göz önünde bulundurulmalıdır. Mültecilik statüsünün beraberinde getirdiği söylemler, göç toplumundaki ev sahibi bireylerin toplum ve medyadaki hâkim sesini oluştururken, mültecilerin yeniden yaşam inşa etme deneyimlerine ilişkin yaşantılarını yansıtan hikâyeler daha az duyulmaktadır. 
Bu makalede Holland, Lachicotte, Skinner ve Cain (1998) tarafından geliştirilen kimlik kuramının bir alt alanı olarak "Kurgulanmış Dünyalar" kuramı kullanılarak, Türkiye'de yaşayan Suriyeli çocukların temel eğitime dahil olma sürecindeki deneyimleriyle birlikte aile ve çocukların bu süreçteki eylemlilikleri ve yaşantıları incelenmiştir. Holland ve diğerleri (1998) bireylerin kimliklerini ve kimlikleri ile ilişkili etkinliklerini (başka bir deyişle, günlük yaşamda gerçekleştirdikleri eylemleri), salt ait oldukları kültürün temel özellikleri ışığında anlamaya çalışmanın yeterli olamayacağını öne sürer. Bu bakış açısına göre, kültürün etkisiyle icra edilen eylemlerle birlikte, insanlar bireysel inisiyatiflere sahiptir. İlgi, ihtiyaç ve hedefleri doğrultusunda bireyler kendilerine özgü dünyalar kurgularlar ve bu dünyaların içerisinde aktif hareket ederek etki ve değişim yaratabilme gücüne sahiptirler. Bireyler kurguladıkları dünyalar içinde, zaman ve mekâna bağlı olarak, rollere bürünüp etkinlikler gerçekleştirirler ve başkalarının etkinliklerinde aktör olarak yer alırlar. Yalnızca kendileri için değil başka insanlar için de dünyalar kurgularlar ve bu doğrultuda etkinlikler gerçekleştirirler. Örneğin, Suriyeli bir öğrenci, öğretmeni tarafından “Türkçe dil yetkinliği olmayan yetersiz bir öğrenci", "Türkçe öğrenme sürecinde olan çift dilli bir öğrenci" ya da "çift dillilik becerisine sahip yetenekli bir öğrenci" gibi farklı şekillerde kurgulanabilir. Bu farklı kurgulanma biçimleri, öğretmenin etkinliklerine, diğer bir deyişle, öğrenciden beklentilerine, öğrencinin neyi ne kadar yapabileceğine dair algısına, inancına ve sınıf içi uygulamalarına yansır (Allexsaht-Snider, Vazquez Dominguez, Buxton ve Karslı, 2017).

Holland ve diğerlerine göre (1998) kimlik, kurgusal dünyalar içerisinde gerçekleşen tüm bu etkinlikler yoluyla yapılanır. Bu kimlik yapılanması süreci esnek ve değişken olup, her daim bir devinim içerisindedir. Kurgulanmış dünyalar içinde kimlik oluşumu iki şekilde gerçekleşir: (1) Bireyler, kendileri için tasavvur ettikleri kimliğe bürünmelerini sağlayacak roller tahayyül ederek etkinlikler gerçekleştirirler. (2) Bireyler rolleri doğrultusunda, gerçekleştirdikleri etkinlikler aracılığıyla başka insanlar ile etkileşime girdikçe ya da başkalarının etkinliklerine katıldıkça kendi etkinlikleri, dolayısıyla rol ve kimlikleri doğaçlamalar yoluyla yeniden şekillenir (Urrieta, 2007). Örneğin, Türkiye'ye gelmiş Suriyeli bir annenin kendisi için tasavvur ettiği "ilgili ve özverili anne" kimliği doğrultusunda kurguladığı dünyada, çocuğu için eğitim olanaklarını araştırması, çocuğunu geçici eğitim merkezinden alarak bir devlet okuluna kayıt ettirmesi, evde çocuğunun eğitimine destek olma çabası ve okul için gerekli olan kaynakları sağlamak için arayışlara girmesi buna örnek teşkil edebilir. Öte yandan, çocuğun öğretmeninin aynı anne için kurguladığı dünyada, annenin okula gelmemesi, öğretmen ile iletişime geçmemesi, çocuğunun okul ihtiyaçlarını karşılayamaması gibi etkinlikleri sebebiyle öğretmen tarafından "ilgisiz anne" olarak kurgulanabilir. Öğretmen ve anne iletişime girdikçe, annenin kendisi için kurguladığı dünya ile öğretmenin anne için kurguladığı dünyanın örtüşmediği görülür. $\mathrm{Bu}$ çelişki kişilerin birbirlerine karşı beklentilerinde, davranışlarında, kurdukları örtük ve açık iletişim biçimlerinde kendini gösterir. Aralarındaki iletişimin niteliğine bağlı olarak annenin kendi kimliğine ilişkin algısı ya da öğretmenin annenin kimliğine ilişkin algısı, diğer bir deyişle, kurguladıkları dünyalar bir devinim içerisinde yeniden şekillenir. Bu şekillenme, bir kişi ya da grubun kurgulanmış dünyasını ve o dünyadaki aktörlerin rol ve sınırlarını kabul etme, reddetme ya da uzlaşmaya çalışma biçimlerinde olabilir (Urrieta, 2007).

Holland ve diğerleri (1998) güç dengeleri, imtiyazlık durumu ve hiyerarşik ilişki örüntülerinin, bireylerin kendileri ve başkaları için kurguladıkları dünyaların içine her daim işlenerek insanların kurgulanmış dünyalarda ne şekillerde konumlandığının belirleyicisi olduğunu söyler. Başka bir ifade ile sosyal sınıf, farklı kültürel yapılar, inanışlar, dil farklılıkları, bireylerin engel(sizlik)leri ve toplumdaki önyargı barındıran baskın söylemler, bireylerin birbirlerinin dünyasında nasıl kurgulandıklarını etkiler. Bu etki o kadar güçlüdür ki belirli gruplara ait bireyler, bazı gruplara ait diğer bireylerin birtakım kurgulanmış dünyalarına giremezler ya da onların kurgulanmış dünyalarının varlığı daha az kabul edilir, daha az görülür ve duyulur (Urrieta, 2007).

Paylaşılan bu kuram ışı̆̆ında, yapılan araştırmanın amacı da Suriyeli aileler ve çocukların, çoğu zaman erişimimiz olmayan, sık duyulmayan ve tanık olunmayan kurgulanmış dünyalarını keşfetme ve ortaya çıkarmaktır. Mülteci statüsündeki aile ve çocukların kurgulanmış dünyalarına ise bu makaleye veri olan araştırmalar kapsamında kaydedilen ve derlenen hikâyeler ve bu hikâyelere işlenmiş yaşantıların incelenmesi aracılığıyla erişilmiştir. Bir sonraki bölümde, mülteci statüsünde bulunan aile ve çocukların kurgulanmış 
dünyalarını keşfedebilmemize bağlam sağlayan, karşıt hikâyelerin özellikleri ve önemi açıklanmıştır.

\section{Anlatılmayan Karşıt Hikâyeler}

Bu çalışmada mülteci statüsüne sahip çocuklar ve ailelerin kurgulanmış dünyaları, karşıt hikâyeler bağlamında ele alınmıştır. Karşıt hikâyeler (counter-narratives) içinde bulunduğu toplumun baskın yapısından etnik, kültürel, dilsel yönleriyle farklılaşan toplulukların, toplumda yer alan genel kalıplaşmış kanılar ile bağdaşmayan, çelişen ve önyargılara karşı duran yaşam deneyimlerini konu alan ve sosyal adalet adanmışlığı ile yaygınlaştııılan anlatılardır (Solorzano ve Yosso, 2002). Karşıt hikâyeler kamuya açık alanlarda, medyada, resmî kurumlarda kısacası toplumsal yaşamının süregeldiği fiziksel ve sembolik mekanlarda, peşin hükümler ve olumsuzlukların ön plana çıkarıldığı yaygın söylemlere, karşı söylemler geliştirmeyi hedefler.

Eleştirel Irk Kuramı kapsamında Solorzano ve Yosso (2002) tarafından kavramsallaştırılan karşıt hikâyeler, pedagojik, kuramsal ya da metodolojik birer araç olarak kullanılabilirler. Bu araştırmada ise karşıt hikâyeler veri setini oluşturmuş ve araştırma sorusunun cevaplanmasını mümkün kılan metodolojik bir araç olarak ele alınmıştır. Karşıt hikâyeler bilimsel çalışmalarda şu şekillerde ele alınabilir: (1) Araştırmacılar kendi yaşam deneyimlerinden yola çıkarak, kendilerine ait karşıt hikâyeleri anlatırlar, (2) araştırmacılar başkalarından dinledikleri ve/veya tanık oldukları karşıt hikâyeleri anlatırlar, (3) araştırmacılar hem kendilerine ait, aktörü oldukları karşıt hikâyelerin hem de başkalarından dinledikleri hikâyelerin anlatıcısı olurlar. Bu çalışma kapsamında ele alınan hikâyelerde ise araştırmacılar tanık oldukları ve dinledikleri karşıt hikâyeleri incelemişlerdir.

Howard, Thomson, Nash ve Rodriguez (2016), kültürel ve dil yapıları sebebiyle toplum genelinden farklılaşan bireylerin yaşam ve eğitim deneyimlerini anlamaya odaklanan araştırmacıların, çalışmaları süresince pek çok karşıt hikâye ile karşılaştıklarını fakat zaman zaman bu hikâyelerin fark edilmesinin zor olabildiğini ya da uzun zaman aldığını ve farklı araştırma sorularına cevap arayan çalışmalarda gözden kaçabildiğini ve böylelikle anlatılmayan hikâyelere dönüştüklerini belirtmişlerdir. Castro-Salazar ve Bagley (2010) ise karşıt hikâyelerin fark edilmemesi, anlatılmaması, duyulur kılınıp yaygınlaştırılması, toplumda önyargılarla beslenerek anlatılagelen söylemlerin ve bu söylemlerle harmanlanan eylemlerin varlıklarını sürdürmesine dolaylı şekilde sebep olduğunu belirtmiştir. Bu sebeple mültecilik, göç gibi deneyimler yaşamış, kültürel ve dil yapıları sebebiyle içinde yaşadığı toplum genelinden farklılaşan ve yaşamlarında ekonomik ve sosyal sıkıntılar barındıran bireyler ile çalışan araştırmacıların temel sorumluluklarından biri, karşıt hikâyelere kulak verme, bir diğer deyişle, insanların yaşantılarını yalnızca zorluklar, sıkıntılar, travmatik deneyimler çerçevesinde değil iyileşme, direnç gösterme, zorlukların üstesinden gelme gibi çok yönlü yaşantıları çerçevesinde ele almaktır.

Solorzano ve Yosso (2002) kişilerin gerçek yaşantı ve anılarının karşıt hikâye olarak nitelendirilebilmesi ve kuramsal, metodolojik ya da pedagojik birer araç olarak kullanılabilmesi için Eleştirel Irk Kuramı'nın (Ladson-Billings ve Tate, 1995) şu beş temel özelliğine sahip olması gerektiğini belirtirler: (1) Karşıt hikâyeler içinde bulunduğu toplumun yaygın kültürel yapısından dil, din, etnik köken ve inanç gibi özellikleri ile farklılaşan bireylerin bu farklılıklardan kaynaklı yaşam deneyimlerini, güçlü yönlerine odaklanarak anlatır. (2) Bu bireylerin yaşamlarında etnik kökenin etkisini ön planda incelese de etnik köken, sosyal sınıf, toplumsal cinsiyet gibi öğelerin etkilerini ayrı ayrı değil, kesişimsel bir yaklaşımla ele alır. (3) Bu bireylerin yaşam deneyimlerini anlama sürecinde geleneksel kuramlar ve araştırma yöntemlerini sorgular. (4) Bireylerin deneyimlerine kadın çalışmaları, sosyoloji, tarih gibi alanları göz önünde bulundurarak disiplinlerarası bir anlayışla yaklaşır. (5) Hikâyeler yoluyla etnik köken, sosyal sınıf ve toplumsal cinsiyete dayalı ayrımclıklara özgürleştirici ve dönüştürücü çözümler getirmeye çabalar (s. 24).

$\mathrm{Bu}$ araştırma kapsamında da Türkiye'de yaşayan mülteci statüsünde bulunan çocuklar ve ailelerin deneyimlerini incelenirken, yukarıda belirtilen özellikleri barındıran yaşantılar karşıt hikâyeler olarak ele alınmıştır. Hikâyelere işlenmiş yaşantılar incelenirken, mülteci aile ve çocukların deneyimlerine çok yönlü bir açıdan yaklaşılmıştır. Bu makale yoluyla, sosyal adalet adanmışlı̆̆ ile hikâyelerin duyulur kılınması, eğitim 
Türkiye'de Yaşayan Suriyeli Çocuklar...

bilimciler ve eğitim uygulayıcıları tarafından benimsenip yaygınlaştırılması ve bu tür başka karşıt hikâyelerin gün yüzüne çıkarılması hedeflenmiştir.

\section{Yöntem}

Türkiye'de yaşayan Suriyeli çocuk ve ailelerin yaşam deneyimlerinin özellikle eğitimsel boyutunu bütüncül bir şekilde anlamayı hedefleyen bu çalışmaya şu iki araştırma sorusu esin kaynağı olmuştur: (1) Türkiye'de yaşayan Suriyeli aileler ve çocukların erken çocukluk eğitimi hizmetlerine erişimlerine ilişkin anlatılmayan, sık duyulmayan karşıt hikâyeler nelerdir? (2) Türkiye' de yaşayan Suriyeli çocuklar ve ailelerine ilişkin anlatılmayan, sık duyulmayan karşıt hikâyeler, çocuklar ve ailelerin kurgulanmış dünyalarına dair neler ifade etmektedir? Bu araştırma sorularının cevaplanmasını esas alan çalışmada, bir önceki bölümde ayrıntılı şekilde aktarılan karşıt hikâyeler yöntemsel bir çerçeve olarak kullanılmış (Solorzano ve Yosso, 2002), bir diğer deyişle iki araştırma sorusunu şekillendirerek veri setinin ortaya çıkmasını mümkün kılmıştır. Karşıt hikâyeler çerçevesinde ele alınan veri setinin analizinde ise "hikâye analizi" (Polkinghorne, 1995; Richmond, 2002) yöntemlerinden faydalanılmıştır. Bir sonraki bölümde araştırmanın yöntemsel boyutu araştırmanın bağlamı, katılımcılar, veri toplama ve analizi bölümleriyle birlikte ayrıntılı paylaşılmıştır.

\section{Hikâyelerin Bağlamı}

Bu çalışmada, 2015 yılından başlayarak Suriyeli çocuklar, aileleri ve öğretmenlerine yönelik Ankara, Gaziantep, Mardin, Hatay, İstanbul ve Şanlıurfa kentlerinde, araştırmacılar tarafından yürütülmüş ya da halen yürütülmekte olan toplam sekiz farklı araştırma ve proje ele alınmıştır². Bu birbirinden farklı araştırma ve projeler, nispeten farklı araştırma sorularına cevap aramakta olsalar da kesişim noktalarında Türkiye'de yaşamaya başlayan Suriyeli mülteci çocuklar, aileleri ve öğretmenlerinin deneyimlerini eğitimsel yaşantılarına odaklanarak anlamaya çalışmak; mülteci çocuklar, aileleri ve öğretmenleri için destek mekanizmaları yaratmak ve/veya var olan mekanizmaların verimliliğini incelemek yatmaktadır. Sekiz farklı araştırma ve projede yer alan öğretmenler, kendi dil yetilerine veya çalıştıkları çocuklar ve ailelerin konuştukları dillere göre Türkçe veya Türkçe-Arapça dillerinde iletişim kurmuşlardır. Araştırma ve projelerin bir diğer temel ortak özelliği ise ağırlıklı olarak nitel araştırma yöntemleri ve eğitim etnografisi ilkeleri (Erickson, 1992) kapsamında gerçekleştirilmiş olmaları ve erken çocukluk dönemini kapsıyor olmalarıdır. Araştırma ve projelerin katılımcı dahil etme süreçleri gönüllülük esasına dayanarak gerekli resmi izin süreçlerinin yerine getirilmesi ile gerçekleştirilmiştir.

\section{Katılımcilar}

Bu makalede ele alınan araştırma ve projelerde yer alan karşıt hikâyelerin aktörleri olan katılımcılar, 2011 yılından günümüze kadar çeşitli zaman dilimlerinde Suriye'den Türkiye'ye göç etmiş, geçici koruma statüsünde olan ve Ankara, Gaziantep, Mardin, Hatay, İstanbul ve Şanlıurfa' da ikamet eden Suriyeli çocuklar ve ailelerdir. Katılımcıların bir diğer ayırt edici ortak özelliği ise, Türkiye' de çeşitli eğitim olanaklarına erişim sağlamış Suriyeli çocuklar ve aileler olmalarıdır. Bir diğer deyişle, katılımcıları; devlet okuluna devam eden Suriyeli çocuklar ve aileleri ve/veya sivil toplum kuruluşları tarafından sağlanmış eğitim olanaklarına erişim sağlamış Suriyeli çocuklar ve aileleri oluşturmaktadır. Hikâyelerde yer alan çocukların yaş aralığı genellikle 4-9 arasındadır ve en az birer kardeşe sahiptirler. Hikâyelerde nadiren de olsa babalar, büyük ve küçük kardeşler ve büyükanne, büyükbabaların da yer aldığı görülmekteyken, çok büyük bir bölümünde anneler yer almıştır. Annelerin ortak özellikleri arasında çocukların eğitim ve bakım sorumluluğunu üstlenmiş olmaları, çalışmıyor olmaları ya da esnek çalışma zamanlarına sahip olmaları sayılabilir.

\section{Veri Toplama Yöntemleri}

Bu makaleye konu olan araştırma ve projeler kapsamında, yarı-yapılandırılmış görüşmeler, gözlem kayıtları ve saha notları temel veri toplama yöntemleri olarak kullanılmış ve bu yöntemler yoluyla hikâyelere erişim sağlanmıştır. Yapılandırılmamış gözlem kayıtları devlet okullarına devam eden Suriyeli çocukları ders

${ }^{2}$ Araştırma ve projelerin listesi makale sonunda belirtilmektedir. 
esnasında gözlemlerken, aile ve öğretmenin okulda bir araya geldiği ya da araştırmacıların okul ortamında aile ile bir araya geldiği uygulamalar kapsamında gözlemler yapılırken tutulmuştur. Benzer şekillerde, sivil toplum kuruluşları tarafından sunulan eğitim programlarında çocuklar gözlemlenirken ve aile ve öğretmenlerin/eğitim uygulayıcıların bir araya geldiğini durumlarda gözlem kayıtları tutulmuştur. Tüm proje ve araştırmalar kapsamında, aile üyeleri ve çocuklar ile Türkiye'deki yaşam deneyimlerini özellikle eğitim boyutuna odaklanarak anlama üzerine kurulu yarı-yapılandırılmış görüşmeler gerçekleştirilmiştir. Türkçe iletişim desteğine ihtiyaç duyulduğu durumlarda çevirmenler aracıllğıyla görüşmeler gerçekleştirilmiştir. Böylelikle hikâyeleri birinci ağızdan, onları yaşayan insanlardan duyma olanağına sahip olunmuştur. Bu makalede ele alınan ve ağırlıkla etnografik (Erickson, 1992) ve nitel araştırma ilkeleri kapsamında gerçekleştirilen çalışmalar süresince hem gözlemlerimizden doğan yorumlarımızı hem de araştırmacı olarak sahada hissettiğimiz çeşitli duygu durumlarımızı, tepkilerimizi, anlık ve sonrasında gelişen fikirlerimizi kaleme aldığımız saha notları (Emerson, Fretz ve Shaw, 2001) tutulmuş ve bu notlar da veri setinin bir parçası olarak ele alınmıştır.

Bu yöntemler ile oluşturulan büyük veri setleri bir araya getirilerek taranmış ve çalışmada odaklanılan araştırma sorularını cevaplayabilecek yaşantılar seçilerek karşıt hikâye veri seti oluşturulmuştur. Karşıt hikâyeler seçilirken, bir önceki bölümde ayrıntılı paylaşılan, Solorzano ve Yosso'nun (2002) herhangi bir deneyimin ve yaşantının karşıt hikâye olabilmesi için sahip olması gerektiğini belirttiği 5 farklı özelliği taşıyan yaşantılar seçilerek karşıt hikâyeler veri setine dahil edilmiştir. Özetle, ailelerin güçlü yönleri ve olumlu deneyimlerinden bahseden, mültecilik statüsü dışında sahip oldukları deneyimler, değerler ve potansiyelleri göz önüne alan, etnik köken dışında sosyal sınıf ve toplumsal cinsiyetin de insan deneyimleri üzerindeki etkilerini bütüncül şekillerde yansıtan yaşantılar veri setine dahil edilmiştir. Bu tarama sonucunda toplam 32 karşıt hikâye belirlenmiştir. Suriyeli öğrenciler ile çalışan öğretmenler ve eğitim uygulayıcılarla yapılan yarıyapılandırılmış görüşmelerde, araştırmacılar tarafından fark edilen birtakım karşıt hikâyelerin, öğretmenlerin de anlatılarında yer aldığı görülmüştür. İki farklı araştırmacının muhakemeleri ile birlikte, öğretmenlerin de benzer yargılarının bulunması üçgenleme yoluyla araştırmanın nitel güvenilirliğine katkı sağlamıştır (Yıldırım ve Şimşek, 2018). Bu hikâyelerin bir sonraki bölümde açıklandığı şekliyle sistematik bir çerçevede analiz edilmesi sonucu bulgulara ulaşılmıştır.

\section{Hikâye Analizi}

Hikâye temelli araştırmalar kişilerin deneyimlerinin karmaşık olduğunu ve çeşitli çelişkiler barındırdığını varsayar (Boutte ve Jackson, 2014). Bu deneyimleri yansıtan hikâyelerin de objektif olma kaygısından ziyade, kişilerin sübjektif yaşantılarına en yaklaşan şekilde anlatılır olmasının önemli olduğunu (Polkinghorne, 1995; Richmond, 2002) ve hikâyelerin mutlak doğruluğunun sorgulanmasının yerine kişiler tarafından ne şekillerde yaşanıp hissedildiği ve aktarıldığının önemli olduğunu öne sürer (Boutte ve Jackson, 2013). Bu bakış açısı benimsenerek yapılan hikâye analizinde, hikâyeler bütüncül olarak ele alınmış aynı zamanda her bir hikâyenin kendi içerisinde tümevarım yöntemi ile detaylı şekilde analiz edilmesi itibariyle iki paralel seviyede yapılmıştır. Bu süreçte araştırmacıların hem bireysel yaşam deneyimleri hem de profesyonel anlamda çokkültürlü ülkelerde yaşamış olmaları ve çokkültürlü ve çokdilli bireyler ile çalışma deneyimlerine sahip olmaları, analiz sürecinde katılımcı deneyimlerini iç görü ile anlama ve yorumlamalarına katkı sağlamıştır.

Clandinin ve Connelly'nin (2000) belirttiği üzere, hikâye analizinde, hikâyeler bağlam (hikâyenin geçtiği fiziksel ya da sembolik mekanlar), devamlılık (hikâyelerde yer alan kişilerin geçmiş, şimdiki an ve gelecek yaşantıları) ve ilişkisellik (kişiler arası ilişkiler) göz önünde bulundurularak üç eksende ele alınır. Bu üç ekseni etkileşimli olarak düşünmek hikâyelerin bütünselliğini korumayı sağlar. Diğer yandan hikâyeleri derinlemesine anlayabilmek ve başka hikâyeler ile ilişkilerini ve örüntüleri görebilmek için sistematik şekilde detaylı analiz etmek gerekir. Bu sebeple, veri analizinde Maxwell ve Miller (2008) tarafından tanımlanan kategorize etme ve bağlantı kurma teknikleri kullanılarak, öncelikle her bir hikâye satır satır okunarak kodlar oluşturulmuş, devamında benzer kodların bir araya gelmesi ile iki ana kategori ve toplam beş alt kategori oluşturulmuştur. Kategorilerin oluşturulma aşamasında, hikâyeler içi ve hikâyeler arası kodlar incelenirken, Clandinin ve Connelly'nin (2000) belirttiği şekilde hikâyelerin kendilerine özgü bağlamından kopmamak 
amacı doğrultusunda bağlam, devamlılık ve ilişkisellik anlamında bütünselliklerine dikkat edilmiştir. Tüm bu analiz sürecine Holland ve diğerleri (1998) tarafından geliştirilen kurgulanmış dünyalar kuramı rehberlik etmiştir. Bir sonraki bölümde analiz sonucunda elde edilen bulgular paylaşılmıştır.

\section{Bulgular}

Hikâyelerin derinlemesine analizi neticesinde çalışmanın ortaya çıkan temel bulgusuna göre, anlatılmayan karşıt hikâyeler (1) annenin kurguladığı dünyaları ve (2) çocuğa dair kurgulanan dünyaları yansıtan, iki ana kategoride ele alınabilir (Bkz. Şekil 1). Annenin kurguladığı dünyalar derinlemesine incelendiğinde ise, bu kurgulanmaların hem (1.1) kendine hem de (1.2) başka mülteci annelere ilişkin olduğu ortaya çıkmıştır. Çocuğa ilişkin kurgulanan dünyalar ise (2.1) annenin, (2.2) öğretmenlerin ve (2.3) çocuğun kendine ilişkin kurgulamalarını kapsayan üç farklı şekilde ortaya çıkmaktadır. Bir sonraki bölümde, bu kategoriler, alt kategorileri ile birlikte örnek hikâyeler eşliğinde açıklanmıştır.

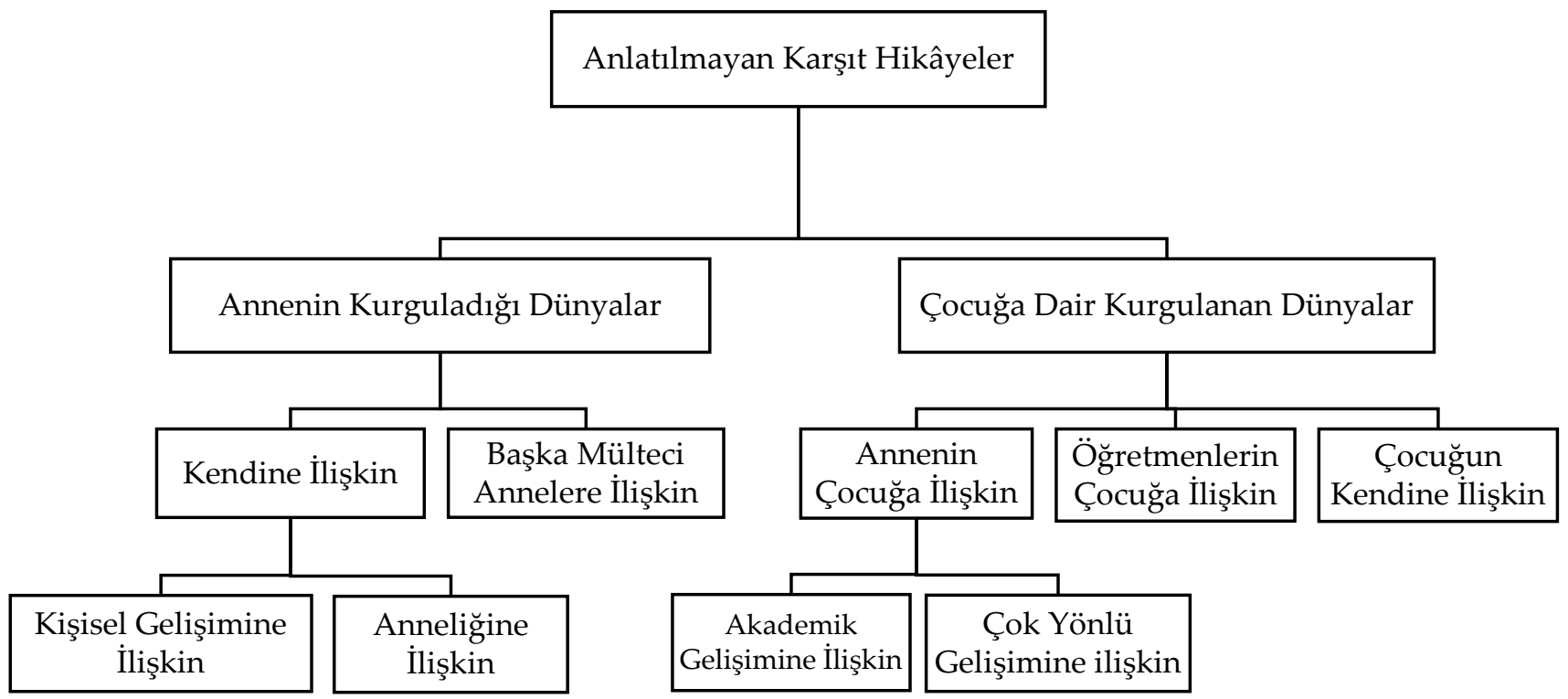

Şekil 1. Çalışma Bulgularının Temaları

\section{Annenin Kurguladığı Dünyalar}

Çalışma kapsamında oluşturulan, anektodal hikâyelerin yer aldığı veri seti sistematik bir nitel kodlama çerçevesinde analiz edilip incelendiğinde hikâyelerin önemli bir kısmında annelerin baş aktör olarak yer aldığ 1 görülmektedir. Bu hikâyelerde, annelerin bireysel yaşam deneyimi ve mücadeleleri ile birlikte, sosyal bağlarının önemli bir parçası haline gelmiş olan diğer mülteci anneler ile iletişim, deneyim ve dayanışmaları da yer almıştır. Annelerin kendileri ve diğer annelere dair kurguladıkları dünyaları temel alan bu iki kategori ve alt kategorileri yansıtan bulgular, hikâyelerden alıntılar eşliğinde aşağıda paylaşılmıştır.

\subsection{Kendine İlişkin Kurguladığı Dünyalar}

Annelerin göç edilen ülkede edindikleri yeni deneyimler ve ortaya çıkan yeni ihtiyaçları doğrultusunda hem kişisel gelişimlerine hem de anneliğe yönelik çaba ve mücadele içeren eylemler gerçekleştirdikleri görülmektedir.

1.1.1. Kendi Kişisel Gelişimine İlişkin: Farklı proje ve etkinlikler kapsamında gözlemlenen hikâyeler incelendiğinde, mülteci annelerin özellikle Türkçe dil desteği alabilecekleri ve mesleki bilgi ve beceri edinebilecekleri olanakları değerlendirme konusunda istekli ve aktif oldukları gözlemlenmiştir. Aşağıda, bu durumu örneklendiren bir hikâye paylaşılmıştır: 


\section{Hikâye 1}

2016 yılı Güz döneminde Ankara'da yer alan bir üniversitede Okul Öncesi Öğretmenliği lisans programı kapsamında verilen Toplum Hizmeti dersinde, Suriyeli öğrencilerin yoğun olduğu bir devlet okulunda gözlem yapan lisans programı öğrencileri, Mamak'ta yer alan, belediyeye bağlı Aile Bilgi Merkezi'ni keşfedip merkezde sunulan dil eğitimleri, meslek edindirme kursları, aile danışmanlığı ve kreş hakkında bilgi edinmiştir. Sonrasında Aile Merkezi'nin yakınında yer alan, gözlem yapmakta oldukları devlet okulunda çalışan idareciler ve öğretmenler ile iş birliği kurarak, Suriyeli aileleri bu hakkında bilgilendirici ve onları merkezi tanımaya yönelik yapılacak bir aile gezisine Arapça ve Türkçe çift dilli notlar ile davet etmişlerdir. Okulda çocuğu bulunan Suriyeli annelerin tamamına yakını geziye katılmış, aile merkezine yoğun ilgi göstererek, merkez idarecisi ve çalışanlara, bireysel gelişim olanakları ile ilgili sorular yönlendirmişlerdir. Merkez idaresinden alınan bilgiye göre, mülteci anneler ilerleyen zamanlarda merkezdeki kurslara, özellikle Türkçe derslerine uzun süreli katılım göstermişlerdir.

Hikâye 1'de yer aldığ 1 şekliyle, anneler kendilerine olanak ve kaynak sunulduğunda, katılım göstermekte ve bu katılımlarını zamanla sürdürmektedirler. Annenin kişisel gelişimini konu edinen diğer hikâyeler ise annelerin katılımcı davranışlarının, kendilerine olanak ve kaynak sunulmasıyla sınırlı olmadığını göstermiştir. Aşağıda yer alan hikâyede örneklendirildiği üzere, mülteci anneler bireysel inisiyatif alarak kendi gelişimleri için aktif kaynak ve çeşitli olanak arayışı içerisine de girmektedirler.

\section{Hikâye 2}

Birkaç anne sosyal medya yoluyla, bir anne de yüz yüze iletişimde Arapça ve Türkçe ortak dil olmadığı durumlarda, temel İngilizce ile iletişim kurarak, araştırmacılardan kendileri için Türkçe kitaplar gibi kaynaklar edinme konusunda destek talep etmişlerdir.

Bu durumu örneklendiren başka hikâyelerde ise, anneler öğretmenler, okul idarecileri, araştırmacıların bulundukları proje etkinliklerinde, açık şekillerde Türkçe okuma-yazma ve Türkçe dilini etkin şekilde öğrenme konusunda eğitim almaya istekli olduklarını belirtmişlerdir. Bununla birlikte, bu tür hizmetlerden faydalanabilme noktasında yaşadıkları ve aşılmasını diledikleri zorlukları da açık şekillerde ifade etmişlerdir. Örneğin, bakmakla yükümlü oldukları küçük çocuklarının olması sebebiyle, çocuk bakım hizmeti sunulmayan faaliyetlere katılamamaları ya da toplu taşıma masrafı sebebiyle mahalleleri dışında sunulan kurslara devam edememeleri gibi. Annelerin paylaştıkları hikâyelerde göze çarpan bir diğer eylem de mahallelerinde yaşayan yerel kadınlar ile kurdukları dayanışmaları konu edinmektedir.

\section{Hikâye 3}

Mülteci anneler, aynı mahalleyi paylaştıkları ve ibadet amaçlı bir araya geldikleri yerel kadınların varlığından bahsetmişlerdir. Komşuluk ilişkisi de sürdürdükleri bu kadınlara, günlük yaşam soru ve sorunları ile ilgili danıştıklarını ve onlardan Türkçe öğrenmeye gayret gösterdiklerini şöyle paylaşmışlardır: "Bizim Türkçe hocamız var, arkadaşımız, evde bize Türkçe öğretiyor. Fatmanur, Arapça da biliyor. Keşke çocuklarımızın da bir saat de olsa böyle bir imkanları olsa."

Paylaşılan alıntıda görüldüğü üzere, kadınlar kendileri için bir öğrenme olanağını yarattıklarını belirtmişler ve benzer bir olanağın çocukları için de mevcut olmasını arzu ettiklerini dile getirmişlerdir.

1.1.2. Anneliğine İlişkin: Mülteci annelerin anneliğe ilişkin pratiklerinin, çocukları ve/veya kendilerinin sivil toplum projeleri ve çeşitli etkinliklere katıldıkça dönüştüğü gözlemlenmiştir. Anneler çocukları ile iletişime geçip çocuklarını gözlemledikçe, proje ve etkinliklerde yer almalarının çocuklarında yarattığı olumlu değişimleri fark etmekte ve bu doğrultuda anneliğe ilişkin yaklaşımlarını yeniden şekillendirmektedirler. Aşağıda bu durumu örneklendiren bir hikâye paylaşılmıştır.

\section{Hikâye 4}

Çeşitli sivil toplum inisiyatiflerinden yararlanmaları sonucunda çocuklarında olumlu değişimler 
gözlemlediklerini belirten mülteci anneler, bu değişimlerin neticesinde "Çocuktaki değişim beni de değiştirdi. Mesela kitaplarını okumasına, yazı yazmasına dikkat eder oldum, 'Şöyle yaparsan daha iyi olur' diye yönlendirir oldum." gibi ifadelerle kendilerini çocuklarına daha uyumlu hale getirmeye ve daha öğrenmeyi destekleyici bir ebeveynlik stiliyle çocuklarına yaklaşmaya yönlendirdiklerini ifade etmişlerdir. Çocukları ile kendilerini artık daha iyi özdeşleştirebildiğini ifade etmişler; çocuklarını daha iyi dinleyip, daha iyi anlamaya başladıklarını, olumlu değişimleri gördükçe sevindikleri, bundan mutluluk duyduklarını belirtmişlerdir. Çocuklarına olan inançlarının arttığını, çocuklarına ilişkin gurur duygularının pekiştiğini ve "Kızım hassas. Onu artık üzmemeye çalışıyorum, okula geldiğinde özlüyorum. Öğretmenleri gibi davranmaya çalışıyorum, onların yaptı̆̆ı gibi iletişim kurmaya çalışıyorum." gibi ifadelerle çocuklarına sosyal-duygusal yönden daha destekleyici yaklaşmaya çalıştıklarını, çocuğuyla olan ilişkisini öğretmenin davranışlarını baz alarak daha duyarlı hale getirmeye çalıştıklarını belirtmişlerdir.

Paylaşılan hikâye ve içindeki alıntılardan anlaşıldığı üzere, mülteci annelerin, çocuklardaki olumlu değişimleri gördükçe kendilerini çocuğun ilgi ve ihtiyaçlarına daha uyumlu hale getirmeye ve daha destekleyici bir ebeveynlik stiliyle çocuğuna yaklaşmaya çaba gösterdikleri görülmektedir. Dolayısıyla çocuğun annede bir değişim başlattığı anlaşılmaktadır. Annelerin çocuklarının ilgi ve ihtiyaçlarına uyumlu ve destekleyici ebeveynlik becerileri yönünde dönüşüm göstermelerinin sebeplerinden birinin; çocuklarının kendileri için artık birer "öğretici" rolü üstlenmiş olmasından ve aile bireyleri ile paylaştıkları bilgi ve becerilerin, anne dahil, bu bireylerin günlük hayatlarını olumlu yönde destekliyor olmasından kaynaklandığı anlaşılmaktadır. Hikâye 5 bu durumu örneklendirmektedir.

\section{Hikâye 5}

Anneler, sivil toplum programlarında çocukların çeşitli bilgi ve beceriler edindiklerini ve bu bilgi ve becerileri kendilerine ve diğer aile bireylerine öğrettiklerini şu şekilde ifade etmişlerdir: "Çocuğum eve kitabıyla gelip 'Burada bunu yaptık, burada şunu yaptık' diye gösteriyor. Evde ondan bir şeyler öğrenmek çok güzel.", "Ben evde resim çizerim. Önceden çocuklarım bana nasıl yaptığımı sorarlardı. Şimdiyse beni yönlendiriyorlar, 'Öğretmenim gibi yap' diyorlar.". Anne şu şekilde devam etmiştir: "Evde bana ve babasına öğrendiklerini öğretiyor.", "Bana bazı kelimeleri Arapça'dan Türkçe'ye çeviriyor, çarşıda pazarda tercümanlık yapıyor. Bana ve abisine Türkçe öğretiyor. Mesela 'araba', 'car', 'seyyara' üçünü de bana söylüyor." Çocuklarından edindikleri bilgi ve beceriler neticesinde anneliklerini dönüştürdüklerini ise şu şekilde paylaşmışlardır: "Çocuğum artık beni dinliyor, beni anlıyor ve bana öğretiyor. Ben de onu daha iyi anlıyorum, cesaretlendiriyorum." Anne somut bir örnek ile şöyle devam etmiştir: "Önceden evde bana yardım etmesini istiyordum, bazı işleri yapmasını bekliyordum ama artık küçük olduğunu fark ettim. Artık okuldan geldiğinde bırakıyorum; oynasın, bana öğretsin, istediği gibi yapsin. Ondan fazla iş beklentim olmuyor artık.".

Hikâyeden anlaşılacağı üzere, annelerin anneliğe ilişkin kurgulanmış dünyalarında çocuk ile etkileşime geçip çocuktaki değişimleri gördükçe, anneliğe dair etkinliklerini olumlu ve destekleyici yönde dönüştürdükleri ve şekillendirdikleri söylenebilir. Bu olumlu evrilme; çocuktaki değişime, düşünce ve davranış bazında kayıtsız kalamayan, çocukla beraber anneliğe ilişkin beceri ve etkinliklerinde dönüşüm gösteren annelere işaret etmektedir.

\subsection{Başka Mülteci Annelere İlişkin Kurguladığı Dünyalar}

Hikâyelerde yer alan mülteci kadınların sosyal ağlarının içinde hem yerel kadınlar hem de kendileri gibi mülteci kadınların varlığı göze çarpmaktadır. Kadınlar, diğer mülteci kadınlara ilişkin kurgulanan dünyalarda, ortak kültür ve benzer göç deneyimleri sebebiyle, göç edilen ülkede yaşanılan zorluklar ve ortaya çıkan ihtiyaçların benzer olduğunu varsaymaktadırlar. Mülteci kadınlar hikâyelerinde, diğer kadınlar ile dayanışma içerisinde olduklarını, özellikle Türkiye'ye ilk geldiklerinde resmi ve bürokratik işlemlerin gerçekleşmesi sürecinde (elektrik ve su aboneliği, ikametgâh gibi muhtarlıkta gerçekleştirilen işlemler, çocukların devlet okuluna kayıt edilmesi gibi) gönüllü destek mekanizmaları kurarak birbirlerine önemli 
ölçüde destek olduklarını şu şekilde paylaşmışlardır.

\section{Hikâye 6}

Sosyal ağ i içinde Türkiye'ye ilk gelenlerden biri olan orta yaşlarda Suriyeli bir kadın, çocukların eğitimine dair zaman içerisinde edindiği bilgi kaynaklarını diğer mülteci kadınlar için hangi şekillerde kullandığını ifade etmiştir. Bu anne durumu şöyle özetlemiştir: "Oğlum okula kaydettirdiğim ilk çocuğumdu. Kaydı çok zor olmuştu. Resmi evraklar eksikti. Kaydettirmek için birçok resmi kuruma gittim geldim. Diğerleri [bu konuşmanın gerçekleştiği ortamda bulunan diğer anneler] sonradan geldiklerinden zor olmadl, onların çocuklarını okula kaydettirmek birlikte yaptığımızdan kolay oldu". Pek çok annenin benzer şekilde, çocuklarının okula kayıt edilmesi sürecine dair birbirlerine bilgi sağlayarak, destek sundukları fark edilmiştir.

Örnek hikâyede görüldüğü üzere, mülteci kadınlar kendi bilgi ve deneyim kaynaklarını benzer ihtiyaçlara sahip olduğunu gözlemlediğini diğer kadınlarla paylaşmaktadırlar. Bununla birlikte, mülteci kadınların birbirleri ile ilişkilerini konu edinen hikâyelerde, iletişimlerinin hızlı ve kuvvetli olduğu ve aralarında güçlü bir sosyal ağın varlığı fark edilmiştir. Diğer hikâyelerde ise, kadınların dışarıda var alan yerel kaynaklara ulaşmada birbirlerini yönlendirici bir rol edindikleri görülmektedir. Bu durumu örneklendiren bir hikâye aşağıda paylaşılmıştır:

\section{Hikâye 7}

Mülteci kadınların birbirlerini haberdar etmesi ve cesaretlendirmesi yoluyla, çok daha fazla kadın ve çocuk proje etkinliklerinin faydalanıcısı ya da yürütülen araştırmaların katılımcısı olmuştur. Örneğin, Ankara'da bir devlet okulunda, öğrencilerin okul çıkışı saatinde çocuğunu okuldan almaya gelen bir mülteci anne ile kısaca görüşülmüş ve mülteci ailelere yönelik, öğretmen ve okul idarecilerinin katılacağı, bir hafta sonra okulda yapılacak olan bir etkinlik paylaşılmıştır. Kendisiyle paylaşım yapılan anne, okulda çocuğu olan diğer tüm yedi mülteci anneyi de haberdar ederek, onlara ulaşılmasına ve bahsi geçen etkinliğe katılmalarına destek olmuştur.

Hikâyede paylaşıldığı üzere, öğretmenlerin/eğitim uygulayıcılarının yetersiz kaldığı durumlarda mülteci kadınlar sunulan hizmetlerin daha çok anneye ve dolayısıyla daha çok çocuk ve aileye ulaşması konusunda anahtar bir rol oynamaktadırlar. Bir diğer deyişle, kadın dayanışması örneği olarak, hizmetlere erişim noktasında birbirini harekete geçiren ve paylaşımcı eylemler gerçekleştirmektedirler.

\section{2. Çocuğa İlişkin Kurgulanan Dünyalar}

Analizler sonucunda elde edilen iki temel kategoriden biri "Annenin Kurguladığı Dünyalar" olmakla birlikte, diğeri "Çocuğa Dair Kurgulanan Dünyaları" yansıtmaktadır. Bu temel kategori altında anneler ve eğitim uygulayıcıların (örneğin, öğretmen ve eğiticiler gibi) çocuğa dair kurguladığı dünyalar ile birlikte, çocuğun da kendine dair kurguladığı dünyaları yansıtan hikâyeler yer almaktadır. Bu hikâyeler genel hatlarıyla mülteci çocukların akademik ve sosyal yetkinlikleri, gelişim ve değişime açık olmaları, çevreleri ile uyumlu şekilde çok yönlü yaşam becerileri edinmekte olduklarını ve tüm bu olumlu süreçlerin de kendileri tarafından bilinçli şekillerde fark edildiğini yansıtmaktadır.

\subsection{Annenin Çocuğa İlişkin Kurguladığı Dünyalar}

Çalışma kapsamında oluşturulan veri seti incelendiğinde, hikâyelerin sayıca önemli bir kısmında mülteci annelerin çocuklarını merkezde konumlandırdıkları ve çocuklarının potansiyellerine dair olumlu algılarının olduğu hikâyelerin varlığı görülmüştür. Bu hikâyelerde annelerin, çocuklarının eğitimine önem vererek onların örgün eğitime dahil olmaları ya da Suriye'de başladıkları eğitime devam etmeleri ve yaygın eğitim olanaklarından faydalanmaları konusunda çaba gösterdikleri fark edilmiştir. Bununla birlikte, hikâyelerde çocukların sadece akademik değil, bütüncül bir şekilde çok yönlü gelişim gösterme potansiyelleri olduğu varsayılarak yakın gözlemler eşliğinde çocuklarına destek oldukları görülmüştür. Bir sonraki bölümde, annenin çocuğun akademik ve çok yönlü gelişimine dair kurguladığı dünyaları örneklendiren hikâyeler 
paylaşılmıştır.

2.1.1. Çocuğun Akademik Gelişimine İlişkin: Bu kategori altında yer alan hikâyelerin ortak temaları ailelerin çocuklarının akademik potansiyellere sahip olduğuna dair inançları ve uygun eğitim ortamlarında çocuklarının gelişebilir ve değişebilir olduklarına dair fikirleridir. Hikâye 8 ailelerin eğitime verdikleri önemi ortaya koymaktadır:

\section{Hikâye 8}

Anneler çocukların geleceğine dair söylemlerinde hangi ülkede veya hangi koşullarda olursa olsun, çocuğun eğitimini sürdürebilmesinin ve eğitimin Suriyeli aileler için mutlak derecede önemli olduğunu açık şekillerde belirtmektedirler. Proje kapsamında okul müdürü, okul rehber öğretmeni ve sınıf öğretmeni ile bir arada yapılan toplantıda, anneler sık sık çocuklarının karne ve diploma alıp almayacaklarını sormuş ve bu konuda kaygılı olduklarını belirtmişlerdir. Devam eden konuşmalarda, çocuklarının bir sonraki eğitim kademesine (örneğin, lise ve üniversite gibi) geçişte sorun yaşamamasını istediklerini ya da başka bir ülkeye göç etmek durumunda kalırlarsa çocuklarının Türkiye' deki eğitimine dair ellerinde bir belge olmasını istediklerini belirtmişlerdir. Birkaç anne çocuklarının çok zeki olduğunu ve iyi bir liseye gitmesini istediklerini, ileride iyi mesleklere sahip olabilecek yetide olduklarını belirtmişlerdir.

Hikâyede örneklendirildiği şekilde anneler, zorunlu göç ile birlikte, yaşamında pek çok değişim ve sıkıntı ile karşılaşmış olan çocuklarının tüm zorluklara rağmen okula devam ederek, başarılı bir geleceğe sahip olabileceklerine dair bir inanç taşımaktadırlar. Ailelerin eğitime mutlak önem vermesi, birlikte çalışılan öğretmenlerin de Suriyeli ailelere dair gözlemlerinde yer almaktadır.

\section{Hikâye 9}

Bir proje kapsamında mülteci çocuklarla çalışan dört okul öncesi öğretmeni ile yapılan sohbet ve görüşmelerde, öğretmenler ailelerin çocuklarının eğitim süreci ile aktif şekillerde ilgileniyor olmalarını memnuniyetle aktarmışlar ve ebeveyn katılımı/ilgisinin çocuklara dair geliştirdikleri olumlu algıda önemli rol oynadığını dile getirmişlerdir. Öğretmenler, ailelerin çocuğun sadece bakımında değil eğitiminde de bizzat inisiyatif alma çabalarını ve bu doğrultuda kendilerinden rehberlik bekleyerek kaynak arayışında bulunduklarını çeşitli şekillerde belirtmişlerdir: "Aileler çocukların her gün okulda neler yaptıkların merak ediyorlar. Çocuklarına evde yardım edecek bir şey istiyorlar. 'Ben çocuğuma nasıl yardım edebilirim, ne öğretebilirim?' diye bana soruyorlar." Öğretmenlerin, anneler ile olan diyaloglarından paylaştığı diğer örnekler de şu şekildedir: "Buradaki Suriyeli anneler bana hep der ki: 'Onlara kitap vermiyor musunuz? Bize ödev verin, biz yardım edelim. Çocuğuma ne öğreteyim?". "Ben daha 'Çocuk yemeğini yedi mi?' diye soran bir anne görmedim. Ancak eğitimle alakalı konularla sürekli ilgileniyorlar." Öğretmenler annelere dair gözlemlerine şu şekilde devam etmişlerdir: "Anneler bilinçli ve kararl. Okula ve eğitime çok önem veriyorlar. Çocuk da haliyle onu gördüğ̈̈ için anneden babadan, o da ister istemez ilgili bir şekilde sinıfa devam ediyor." Ebeveyn katılımını/ilgisini memnuniyetle karşılayan ve takdir eden bu öğretmenler, proje boyunca anneler ile yakın bir bağ kurmuş, anneler öğretmenleri evlerine davet etmiş, beraberce sosyalleşmek için günlük hayatta 'çay partileri' gibi ortamlar düzenleyerek bir araya gelmişlerdir. Anneler ile çocuğun eğitimi sayesinde yakın bir bağ kuran öğretmenler, zaman zaman sadece sınıfın değil, bağ kurdukları annelerin evlerinin de birer 'hane öğretmeni' olduklarını paylaşmışlardır.

Öğretmenlerin anlatıcısı olduğu bu hikâyeden de anlaşılacağı üzere, ailelerin çocuğun eğitim sürecine ilgi duyarak, bu sürece aktif şekilde katkı sağlayabilmek için öğretmenlerden yönlendirme talep ediyor olması ve bu karşılıklı etkileşimsel paylaşımların okul ötesinde sosyal mecralara taşınmış olması göze çarpmaktadır.

\section{Hikâye 10}

Çocuklarının eğitim görebilmesi ve öğrenmesi konusunda oldukça duyarlı ve bunun için destek kanalları arayan anneler çocuklarını İstanbul'da bir sivil toplum örgütü tarafından sunulan 
Türkçe ve Arapça olmak üzere çift dilli eğitim veren okul öncesi eğitimi programına kayıt ettirmişlerdir. Çocuklarının temel eğitime hazırlanabilmesi ve Türkiye'deki eğitim sistemi içerisinde yer alabilmesini önemsedikleri için çocuklarının bu okul öncesi eğitim programında yer almasını istediklerini belirtmişlerdir. Çocukların örgün öğretim hayatlarına Türkiye'de Türkçe bir eğitim sistemi içerisinde devam edecek olduklarını ve anavatanlarına geri dönüp dönmeyeceklerinden emin olmadıkları için uzun yıllar Türkiye'de yaşayabilecekleri ve kendileri Türkçe öğrenmeye çalışsalar da bunu yapamadıkları için en azından çocuklarının bu dili öğrenerek aileye tercümanlık yapabilmesi gibi sebepleri dile getirerek, çocuklarının Türkçe öğrenmesini önemsediklerini ve bu beklentiler içerisinde programa kaydettirdiklerini açıklamışlardır.

Hikâyede örneklendirildiği üzere, örgün eğitimin yanı sıra aileler çocuklarının eğitimi için informal eğitim olanaklarından da faydalanmaktadırlar. Bilinçli şekilde, okul öncesi dönemden başlayarak çocuklarının eğitimini desteklemenin önemli olduğunu belirtmekte ve çocuklarının çift dillilik becerileri gündelik yaşamda kendilerine yardımcı olabileceklerinin altını çizmektedirler. Bu kategoride yer alan en son hikâye ise ailelerin çocuklarının akademik gelişim süreçlerini yakinen gözlemleyebildiklerini yansıtmaktadır.

\section{Hikâye 11}

Suriyeli aileler kendilerine iletilen Arapça-Türkçe çift dilli notlar sonrası proje kapsamında hazırlanan çok dilli aile matematik atölyelerine yoğun ilgi göstermişlerdir. Anne, baba ve diğer aile üyeleri (abla, abi, büyükanne ve büyükbaba gibi) atölyelere katılmıştır. Atölyeler süresince anne ve babalar, öğretmenler ve araştırmacılar ile çocuklarının eğitimlerine dair yaptıkları gözlemleri, evde sundukları, sunmak isteyip sunamadıkları destekleri, öğretmenlerden beklentilerini ve memnuniyetlerini net şekillerde ifade etmişlerdir. Örneğin; bir baba, sınıfta akıllı tahta kullanımının kendisinin çok hoşuna gittiğini, öğretmenin tavsiyesi ile çocuğunun ödevlerine destek olmak için bir telefon uygulamasından faydalandığını ve olumlu etkisi olduğunu paylaşmıştır. Bir anne ise, Türkçe bilmemesine rağmen çocuğuna düzenli sesli Türkçe kitap okuma yaptırdığını, Türkçe bilen diğer yaşça büyük çocuğundan kardeşini dinlemesini rica ettiğini ve kendisinin de kitap okuyarak çocuğuna örnek olmaya çalıştı̆̆ını paylaşmıştır.

Aileler, çocuklarının akademik gelişimleri için teknolojinin de entegre olduğu uygun öğrenme ortamlarının önemini fark etmektedirler. Kendileri de çocuklarının eğitimlerinin okul dışında da devam etmesi için çeşitli şekillerde çaba göstermektedirler. Bununla birlikte, yaşça büyük çocuklarını, kardeşlerini akademik anlamda destekleyebilecek birer kaynak olarak görmektedirler.

2.1.2. Çocuğun Çok Yönlü Gelişimine İlişkin: Annelerin çocuğa dair kurgulanmış dünyasının akademik temelli olmasının ötesinde, çocuğun gelişimine dair çok yönlü olması göze çarpan bir diğer tema olarak ortaya çıkmaktadır. Anneler, çocuğun yetkin ve aktif öğrenen olarak kurgulandığı ve bu doğrultuda destekleyici etkinlikler ile çevrelendiği ortamlarda, aile ve mahalle ortamı gibi bağlamlar arası transfer edebileceği çok yönlü hayat becerileri edindiğine ilişkin hikâyeler paylaşmıştır. Yaptıkları detaylı gözlemlerde çocuklarının sivil toplum programlarına katılmaları ile birçok alanda gözle görülür değişimler ve olumlu ilerlemeler kaydettiklerini belirtmişlerdir.

\section{Hikâye 12}

Daha önce kurum temelli herhangi bir eğitim hizmetinden yararlanmamış veya sosyal destek programına katılmamış okul öncesi dönemde çocukları olan 34 Suriyeli anne, çocuklarının İstanbul'da bir sivil toplum kuruluşu tarafından gerçekleştirilen okul öncesi eğitim programına katılmaları neticesinde çocuklarda gözlemledikleri çok yönlü gelişime ilişkin benzer noktaların öne çıktığı hikâyeler paylaşmıştır. Anneler, çocuklarında şu değişimleri gözlemlediklerini belirtmişlerdir: Çocukların çekingen, utangaç ya da ürkek bir mizaçtan daha girişken ve etkileşimsel olmaya doğru değişmesi; arkadaş edinmeye başlamaları, aile bireyleriyle eskisine 
göre ilişkilerinin iyileşip kuvvetlenmesi; çevresindeki bireylerle iletişim kurma sıklıklarının artması ve bu bireylere olan uyum iyiliğinin gelişmesi; ebeveynlerin beklentilerini daha çok yerine getirmeye başlamaları; oyun kurmak için daha fazla fırsat aramaları; malzemelerini ve oyuncaklarını paylaşmaya başlamaları; saldırgan ya da agresif tutumlarından sıyrılıp nispeten daha sakin bir mizaç sergilemeleri; çatışmaları daha uzlaşmacı bir tavırla halletmeye çabalamaları; duygularını ifade etmeleri ve aileye bağımlı iken daha bağımsız olma yolunda davranışlar sergilemeleri gibi. Anneler çocuklarının okul ortamında edindikleri birçok olumlu davranışı ev ve sosyal ortamlarına taşımalarını ise "Artık evde kitaplarıyla zaman geçiriyor. Eve gelince bana öğrendiği Türkçe kelimeleri ya da şarkıları söylüyor. Ben Türkçe bilmediğimden çarşıda pazarda bana çevirmenlik yapıyor." gibi ifadelerle paylaşmışlardır. Çocuklarının özbakım becerileri konusunda ise "Artık yatmadan önce 'Anne diş firçalama vakti' diyor, bana da hatırlatıyor. Yemeğini yedikten sonra tabă̆ını sofradan kaldırıyor, çok şaşırıyorum. Suyu da boşa harcamamayı öğrenmiş." gibi söylemler paylaşmışlardır.

Annelerin hikâyelerine göre çocukların program ve okul ortamında edinip ev ve sosyal çevrelerine taşıdığı davranış değişimleri temel olarak Türkçe dil gelişimi, olumlu ve uyumlu davranışları yansıtan, ev hayatlarında da gözlemlenen sosyal-duygusal ve özbakım becerileri ile ilgilidir. Anneler çocuklarında gözlemledikleri bu çok yönlü değişimleri memnuniyetle karşılamaktadırlar. Bununla birlikte, anneler çocuğun gelecekte hümanist ve idealist değerlerin taşıyıcı olmasını tahayyül etmektedirler. Annelere göre çocuğun insani değerleri öğrenmesi, geleceğine taşıması, bu değerleri savunması ve yayması çok yönlü gelişimlerinin uzun vadede önemli bir parçasıdır.

\section{Hikâye 13}

Okul öncesi dönemdeki çocukları İstanbul'da bir sivil toplum eğitim programına katılan bir grup Suriyeli anne program boyunca eğitim uygulayıcılarla sohbetleri esnasına zaman zaman büyük çocuklarının göç sebebiyle eğitime devam edemediklerinden üzüntü duyduklarını ve bu yüzden insani erdem ve değerleri edinecek ortamlardan yoksun yetiştiklerini belirtmişlerdir. Anneler programa katılan çocuklarının geleceğine dair söylemlerinde ise hangi ülkede veya hangi koşullarda bir hayatları olursa olsun, çocuklarının eğitimini sürdürebilmesi/sürekliliği ve "Ĕ̆itimin Suriyeli aileler için mutlak derecede önemli" olduğunu belirtmişler ve bunun çocuklarının gelecekte "iyiliği savunan", "dünyaya katkı sağlayan", "insanlara faydası dokunan", "barış için mücadele eden", "üretken ve topluma faydalı" bireyler olarak yetişmesi için gerekli en temel şart olduğunun önemini vurgulamışlardır.

Yukarıdaki örnek hikâyede olduğu gibi annelerin zorlayıcı koşullarda dahi çocuklarının insani değerleri ve erdemleri öğrenip geleceklerine taşımalarının mutlak suretle eğitime devam etmeleri sayesinde gerçekleşeceğini içselleştirdiklerini ve bu arzunun çocuklarının geleceğine dair tahayyüllerinin bir parçası olduğu anlaşılmaktadır.

\section{2. Öğretmenlerin Çocuğa İlişkin Kurguladığı Dünyalar}

Öğretmenlerin çocuğa dair kurguladığı dünyaları yansıtan ve benzer yönlere vurgu yapan hikâyelerin varlığı bir alt kategori olarak göze çarpmaktadır. Bu alt kategoride yer alan hikâyelerin ortak teması, ana dilin ve kültürel kaynakların gözetildiği nitelikli eğitim programlarında çocukların akademik potansiyelleri ve sosyal-duygusal yetkinliklerinin ortaya çıabilir ve gelişebilir olduğuna dair öğretmenlerin fikirleridir. Hikâye 14, bir eğitim programında görev yapan öğretmenlerin, mülteci çocuklara ilişkin kurguladıkları dünyaları bu yönden aktarmaktadır:

\section{Hikâye 14}

İstanbul'da bir proje kapsamında, sınıflarında okul öncesi dönemde sadece mülteci çocuklarla çalışan 8 okul öncesi öğretmeni, gelişim becerileri desteğine ihtiyaç duyarak programa başlayan Suriyeli çocukların 2 aylık süreçte gösterdiği kayda değer ilerleme ve dönüşüme ilişkin gözlem ve değişen algılarını dile getirmişlerdir. Öğretmenler, çocukların; sınıfın sosyal ortamına uyum 
sağlama süreçlerindeki kararlılık ve başarılarını, 'olumsuz', 'istenmeyen', 'sınıf kurallarına aykırı' ya da 'çatışmacı' diye nitelendirilebilecek davranışlar sergileyen bazı çocukların giderek daha uzlaşmacı beceriler edinmiş olmaları şeklinde değerlendirmiştir. 'Saldırgan', 'paylaşmaya yanaşmayan', 'şikâyetçi', 'çatışma çıkaran', 'hareketlerini kontrol etme eşiği düşük' olan çocukların, kısa sürede öz-denetim becerileri, duygu kontrolleri ve psikoduygusal durumları geliştikçe, bu davranışları daha olumluya doğru evirdiklerini belirtmişlerdir. Çocukların sergiledikleri olumlu ve yapıcı davranışları örneklerle aktaran öğretmenler, Türkçe dil becerileri geliştikçe çocukların etkinliklere katılım sıklığının arttığını, kendilerini rahatça ifade edebilmede kısa sürede büyük mesafe kat ettiklerini, akranları ve öğretmenleriyle güvene dayalı bağ ve etkili sosyal iletişim becerileri geliştirdiklerini, yönlendirme gereken davranışların sınıf iklimine uyumlu şekilde artık daha iyi denetleyebildiklerini şaşkınlık ve memnuniyetle dile getirmişlerdir. Öğretmenler kısa sürede mülteci çocukların bu denli bir dönüşüm göstermesini beklemediklerini paylaşmışlar ve bu kazanımları uyguladıkları programın akademik yönden nitelikli olmasına, sınıf ikliminin çocukların ana dili ve kültürüne duyarlı olmasına ve bu hedef kitleyle çalışmaya özel aldıkları yoğunlaştırılmış eğitime atfetmişlerdir.

Suriyeli çocuklarla çalışmadan önce onların kısa sürede bu tür kazanımlara ulaşmalarını öngörmediklerini belirten öğretmenlerin, mülteci çocukların yetkinliklerine ve potansiyellerine ilişkin algılarını değiştirmek durumunda kaldıkları anlaşılmaktadır. Bu doğrultuda, çocukların kısa sürede kat etmiş olduğu olumlu mesafenin, öğretmenlerin mülteci çocuklara ilişkin kurguladığı dünyayı olumlu şekillendirmesinde anahtar rol oynadığı görülmektedir. Bu durum çocukların öğretmenlerin algısını olumlu yönde değiştirme gücünü ortaya koymaktadır.

$\mathrm{Bu}$ alt kategori altında göze çarpan bir diğer tema ise öğretmenlerin mülteci çocukların "öğrenmeye hevesli" olması sayesinde mesleki bağlılıklarını, dolayısıyla mülteci çocuklarla çalışmaya ilişkin tutumlarını olumlu yönde şekillendirmesidir. Hikâye 15, öğretmenlerin, mülteci çocuklarla çalışırken mesleki kimlik algıları ve mesleki doyumlarında, çocukların öğrenmeye olan ilgilerinin belirleyici olduğunu yansıtmaktadır.

Hikâye 15

Daha önce mülteci çocukların oluşturduğu sınıflarda çalışma deneyimi olmayan iki okul öncesi öğretmeni, bir proje kapsamında bu deneyimi edindikten sonra proje yürütücüleri ile gerçekleştirdikleri sohbetler ve görüşmeler esnasında, mülteci çocukların mesleki bağlılıklarını arttırdığını şu gibi ifadelerle dile getirmiştir: "Çocuklar öğrenmeye açlar, ne verirsek almaya bakıyorlar.", "Çocukların istekli olmaları, insanı mutlu ediyor; daha da işine bağhlyor.", "Bu çocuklar bana "öğretmen öğretmen' diye bakıyorlar, saygı duyuyorlar, beni dinliyorlar.", "İhtiyaçları çok fazla olduğu için daha hızlı öğreniyorlar." Bu öğretmenler program sonunda özellikle mülteci çocukları da kapsayan eğitim projeleri ve sivil toplum çalışmalarında görev almak için bizzat sosyal ağlar geliştirmiş ve kapsamlı bir fırsat arayışı içine girmişlerdir. Bu arayış neticesinde halen mülteci çocukları ve ailelerini kapsayan projelerde yer aldıkları bilinmektedir.

Hikâyede örneklendirildiği üzere, daha önce mülteci çocuklarla çalışma deneyimi olmayan öğretmenlerin, önceki deneyimlerinde çalıştıkları çocuklarla ulaşmakta zorlandıkları birçok eğitsel amaç ve kazanıma mülteci çocukların daha "alıcı" ve öğrenmeye hevesli, ilgili ve istekli olmaları itibariyle görece daha çabuk ulaşabildikleri ve bunun da öğretmenlerin mesleki kimlik algılarını ve bu kitleyle çalışmaya dair mesleki bağlılıklarını pekiştirdiği anlaşılmaktadır.

\section{3. Çocuğun Kendine İlişkin Kurguladığı Dünyalar}

Mülteci çocuklar zorunlu göç sebebiyle hayatlarında yaşanan değişimler ile birlikte kendilerine dair dünyalar kurgulamaktadırlar. Bizzat çocukların paylaştı̆̆ı hikâyeler incelendiğinde, kendilerini belirli ortamlarda nasıl hissettiklerine, yaşadıkları koşullarda veya katıldıkları programlarda ne gibi hususların kendilerine keyif ve mutluluk verdiğine ve gelecek beklentilerine ilişkin ortak temaların olduğu anlaşılmaktadır. Bu kategori altında yer alan hikâyelerin ortak teması, çocukların kendilerine dair 
kurguladıkları dünyada; okula gidiyor olmanın ve sınıf topluluğunun bir üyesi olmalarının kendilerine normal hayatta sahip olmadıkları fırsatları sunması sebebiyle mutluluk vermesi, yerel akranları ile sosyalleşme arzu ve çabaları; geleceğe dair realist ve hümanist hedeflerinin olmasıdır. Hikâye 16, 17 ve 18 daha önce herhangi bir kurum temelli erken çocukluk hizmetinden veya sosyal destek programından yararlanmayan ve ilkokuldan önce hızlandırılmış bir okul öncesi müdahale programına katılan Suriyeli çocukların bu ortak temalar çerçevesinde kendilerine ilişkin kurguladıkları dünyaları yansıtmaktadır.

\section{Hikâye 16}

Belirtilen programdan yararlanan çocuklara program bitiminde çocuk dostu araştırma yöntemleri yoluyla okul, ev ve mahalle hayatları ile bağdaştırabilecekleri özel olarak profesyonel bir çizimle tasarlanmış resim kartları gösterilmiş ve bunlar üzerine çocuklarla sohbetler gerçekleştirilmiştir. Çocuklar sınıf, program ve okul tutumuna ilişkin resim kartlarında yer alan çocuklar üzerinden kendi iç görülerini, dolayısıyla kendilerine ilişkin kurguladıkları dünyaları, şu ifadelerle yansıtıp paylaşmışlardır: "Çocuklar mutlular. Çünkü okula geliyorlar. Çünkü okulda oyuncaklar var. Okul bize her şeyi öğretiyor." Bir başka çocuk şöyle demiştir: "Çocuklar mutlular. Çünkü bize çok güzel hikâyeler anlatıyorlar.", "Sınıftaki çocuklar hep kartlarını duygu panosuna mutlu olarak işaretliyorlar.". Diğer bir çocuğun ifadeleri ise şöyle olmuştur: "Mutlular, çünkü okuldalar, çünkü Türkçe öğrenecekler, ders çalı̧̧acaklar.", "Seviyorlar, çünkü öğretmenleri var. Öğretmenleri sakin olduğu için seviyorlar. Ondan soru sorduğu için seviyorlar.", "Resim çizdiğimde bana yardım etmelerini (öğretmenin yardımı) seviyorum.". Başka bir çocuğun ifadeleri de benzer niteliktedir: "Mutlu hissediyor çünkü okula gidiyor. Arkadaşları var, arkadaşları onu seviyor, onunla oynamak istiyor. Diyor ki: 'Oynayabilir miyim?', oynuyor.", “Okula gitmeyi seviyor, çünkü arkadaşların istiyor, arkadaşlarıyla konuşmayı istiyor, arkadaşları olsun istiyor.". Çocuklar, okuldan çıkmış ve annesinin yanında evine doğru giden bir resim kartına ilişkin ise şu ifadeleri paylaşmışlardır: "Üzgün, çünkü eve gittiği için sıkılıyor. Evde ne yapacă̆ını bilmiyor. Evde resimleri yok, oyuncakları yok.", "Üzgün, çünkü oyuncaklarla oynayamıyorum. Evde oyuncağım yok.", "Üzgün hissediyor, çünkü evinden sıkılıyor. Oynayabileceği bir şey evde yok.".

Hikâye 16, okul programında yer almanın ve sınıf topluluğunun bir üyesi olmanın, çocukların kendilerine ilişkin kurguladıkları dünyanın önemli bileşenlerinden biri olduğunu yansıtmaktadır. Çocuklar bu kurguladıkları dünyayı; öğrenme, resim çizme, öğretmenin sakin olması ve soru sorması, kendilerine hikâyeler anlatılması, akranları tarafından sevilmeleri ve onlarla oyun oynamaları gibi etkenlerle ilişkilendirmektedir. Ayrıca, okula gidiyor olmanın ve sınıf topluluğunun bir üyesi olmalarının çocuklara okul dışındaki hayatlarında sahip olmadıkları fırsatları sunduğu anlaşılmaktadır.

\section{Hikâye 17}

Mahalle ve ev dışı sosyal ortamlara ilişkin resim kartları gösterilip arkadaş grupları ve sosyalleşme deneyimleri anlaşılmaya çalışıldığında, çocuklar konuya ilişkin ortak noktalara vurgu yapan paylaşımlarda bulunmuştur: "Türk arkadaşlarım yok. Türk arkadaşlarım olsun isterdim.", "En çok Türk çocuklarla oynamayı seviyorum Türkçeyi öğrenmek için. Onlarla tanışamıyorum." Çocuklar duygu ve deneyimlerini anlatmaya şöyle devam etmişlerdir: "Suriyeli arkadaşım olunca klzgin olurum. Türk arkadaşım olunca mutlu olurum çünkü Türkçe konuşuyor.", "Türk arkadaşım yok, çünkü çocukların hepsi bana 'Suriyelisin' diyor." "Sadece Suriyeli arkadaşları var. Türk arkadaşlarım olsun isterdim, çünkü biz istiyoruz birbirimizle oynayalım.". Çocukların birçoğunun bu sohbetlerin belirli noktalarında veya sonunda resimlerde kendilerinin olduğunu ifade etmiş olmaları bu paylaşımlarda esasen kendi düşüncelerini yansıtma ihtimallerinin yüksek olduğunu göstermiştir.

Hikâye $17^{\prime}$ den Suriyeli çocukların kendilerine ilişkin kurguladıkları dünyalarda yerel akranlarıyla sosyalleşmenin önemli bir istek ve arzu olduğu anlaşılmaktadır. Çocuklar paylaşımlarında Türk arkadaşlarının olmadığını ancak olmasını dilediklerini yer yer belirtmişlerdir. Bu dileklerini akranlarından Türkçe öğrenebilmek veya sadece onlar ile oyun oynayabilmek ile ilişkilendirmişlerdir. Çocukların yerel 
akranları ile arzu ettikleri şekillerde sosyalleşemedikleri anlaşılmaktadır.

\section{Hikâye 18}

Programın tamamlanmasına yakın çocuklar ile bir araya gelinmiş ve geleceklerine ilişkin kendilerine nasıl bir hayat kurgulayıp hayal ettikleri üzerine sohbetler gerçekleştirilmiştir. Çocuklar gelecek beklentileri ve isteklerine ilişkin sohbetlerde şu gibi paylaşımlarda bulunmuştur: "Öğretmen olmak istiyorum, çünkü köylülere öğretirim.", "Öğretmen olup çocuklara ögretirse mutlu olur.", "Arapça harfleri yazabileyim isterim. Büyüyünce, beni okula gitmek mutlu eder." Hayallerini paylaşmaya çocuklar şöyle devam etmişlerdir: "Büyüyünce annem için çalışmak beni mutlu eder.", "Ninesinin, dedesinin, arkadaşlarının yanına gitmek için Suriye'de yaşamak isterdi.", "Büyüyünce burada yaşamak isterdim. Burayı seviyorum çünkü burada her zaman su var. Suriye'de sadece akşamları su var.", "Mutlu yaşamak isterdi. Kalbi tertemiz olsun isterdi.".

Hikâye 18 ' de çocukların kendilerine ilişkin kurguladıkları dünyada geleceğe dair öğretmen olmak, okula gitmek, tanıdıklarının yanında olmak için kendi ülkesinde yaşamak ve su temel ihtiyaçları karşılamaya ilişkin sıkıntı çekmeyeceği bir yerde yaşamak gibi realist hedeflerin yanı sıra, birilerine bir şeyler öğretebilmek, aile bireyleri için çalışmak ve mutlu bir hayat hayalini kurmak gibi hümanist hedeflerinin de olduğu görülmektedir. Okula ve öğrenme ortamlarına erişim, meslek sahibi olma, aile bireylerinin var olduğu ve temel kaynaklara sahip olunan bir ortamda yaşama veya sadece mutlu olabilme arzusu, çocukların geleceğine ilişkin tahayyül ettikleri önemli idealleridir.

\section{Tartışma}

Bir üst bölümde belirli kategori ve alt kategoriler altında paylaşılan hikâyelerin oluşturduğu araştırma sonuçları, tartışma bölümünde kuramsal anlamda ve alanyazına ilişkili şekilde iki temel alanda ele alınacaktır. Anne ve çocuklara dair derlenen, anlatılmayan karşıt hikâyeler öncelikle kurgulanmış dünyalar kuramı ışığında yorumlanacak, sonrasında alanyazında mülteci aile ve çocukların eğitime dahil olma süreçlerini karşıt hikâyeler bakış açısıyla incelemiş diğer çalışmalar eşliğinde tartışılacaktır.

Anne ve çocuklara dair anlatılmayan karşıt hikâyeler bir bütün olarak ele alındığında, Türkiye'de yaşamaya başlamış Suriyeli anne ve çocukların bir devinim içerisinde yeni kimlikler inşa ederek kurgulanmış dünyalar yarattıkları görülmektedir. Holland ve diğerlerine (1998) göre bireyler ihtiyaçları, ilgileri ve hayalleri doğrultusunda inisiyatifler alarak kurgulanmış dünyalar içerisinde yeni kimlikler yaratırlar ve bu kimliklere tutarlı şekilde etkinlikler ya da eylemler gerçekleştirirler. Şüphesiz ki tüm bu süreçler insanların düşünme ve yaşam biçimlerine işlenmiş kültürün de etkilerini taşır. Annelere dair paylaşılan ilk üç hikâye, Suriyeli annelerin Türkçe dilini öğrenmek için kurslara katıldıklarını, yerel kadınlar ile kurdukları bağlar yoluyla sosyal bir Türkçe dil desteği aldıklarını, kaynak kitaplar aradıklarını ve mesleki kurslara katılmaya ilgi gösterdiklerinin resmini çizmektedir. Bu hikâyelerde, annelerin göç ettikleri ülkedeki yeni yaşam koşulları içerisinde bireysel kimliklerini "öğrenen", "araştıran", "katılımcı", "kendini geliştiren" şekillerde inşa ettiklerini ya da kimliklerinin daha önce de parçası olan bu öğeleri göç ettikleri ülkedeki yeni eylemleri ile daha da etkinleştirdikleri görülmektedir. Bu süreçler boyunca ise, "destek olma" ve "paylaşma" kültürü doğrultusunda hem yerel kadınlar ile hem de kendileri gibi mülteci statüsünde olan kadınlar ile dayanısma içerisinde oldukları fark edilmektedir.

Benzer şekilde, hikâyelerin önemli bir kısmında annelerin, çocuklarının Türkiye' deki eğitimi ve gelişimine yönelik deneyimleri doğrultusunda, annelik kimliklerini dönüştürdükleri ve bu doğrultuda yeni davranışlar geliştirdikleri, diğer bir deyişle, anneliğe dair yeni dünyalar kurguladıkları görülmektedir. Öncelikle, hikâye $8,9,10$ ve 11 'de Suriyeli annelerin çocuklarının eğitimine büyük değer verdiklerini, çocuklarının okula erişimini ve ilkokula hazırlığını önemseyerek okul dışında sivil toplum kuruluşları tarafından sunulan çift dilli erken çocukluk programlarına dahil olmalarını sağladıklarını ve çocuklarının akademik eğitimine okul dışında destek olmak için çaba harcadıklarını göstermektedir. Hikâye 4 ve 5 'te yer aldığı şekliyle ise, tüm bu süreçte, Suriyeli annelerin, annelik kimliklerini "çocuktan öğrenen", "çocuktan beklentisini çocuğa duyarlı 
biçimde yeniden şekillendiren", "çocuğunu cesaretlendiren" şekillerde inşa ettiklerini göstermektedir. Özellikle, hikâye 4'de bir annenin paylaştığı ve temsil gücü yüksek olan "[Çocuğumun] kitaplarını okumasına, yazı yazmasına dikkat eder oldum, şöyle yaparsan daha iyi olur.' diye yönlendirir oldum" ifadesine odaklanırsak, alanyazında kurgulanmış dünyalar kuramı ışığında mülteci annelerin, annelik kimliklerini inceleyen çalışmalarda da benzer şekillerde çocuklarını destekledikleri görülmektedir. Örneğin, Hsin (2011) çalışmasında, Tayvan'daki Vietnamlı göçmen annelerin, çocuklarının erken okur yazarlık sürecine değer verdiklerini ve bu konuda inisiyatif alarak aktif şekilde sosyal ağlar kurup yöntemler geliştirerek çocuklarına evde destek olmaya çalıştıklarını gözlemlemiştir. Chung'un (2013) Amerika Birleşik Devletleri'nde yaşamaya başlayan Koreli anneler ile gerçekleştirdiği çalışma ise annelerin yeni yaşadıkları ülkede ebeveyn olmak ve okula katılım konusunda yaratıcı ve aktif eylemler ve doğaçlamalar eşliğinde kimlikler kurguladıklarını göstermektedir. Özetle, dünyanın farklı yerlerinde anneler göç ile şekillenen yeni yaşam koşulları içerisinde, kendilerinin ve çocuklarının ihtiyaçlarını, gelişim ve eğitimini önceliklendirerek, aktif şekillerde emek vermekte, iyileşme ve direnç göstererek yaşamlarında değişim yaratmakta, başka bir ifade ile karşıt hikâyelerin öznesi olmaktadırlar.

Urrieta (2007) kurgulanmış dünyalar kuramının ilişkisellik yönünün altını çizerek, bireylerin sosyal birer varlık olarak birbirlerinin eylemlerinden etkilenip birbirlerini farklı şekillerde konumlamaları sonucunda etkinlikler gerçekleştirerek kurgulanmış dünyalar yarattıklarını ve kimliklerini şekillendirdiklerini belirtir. Bu makalede paylaşılan hikâyeler bir bütün olarak düşünülürse Suriyeli annelerin, çocukların ve eğitim uygulayıcılarının birbirlerinin ve başkalarının olumlu eylemlerinden etkilendikleri ve buna karşılık verecek şekilde etkinlikler gerçekleştirdikleri görülür. Örneğin, bir anne "Çocuktaki değgişim beni de değiştirdi [...]onu yönlendirir oldum." derken, öğretmen "Anneler bilinçli ve kararll. Okula ve eğitime önem veriyorlar. Çocuk da onu gördü̈̆̈̈ için anne ve babadan, ister istemez ilgili bir şekilde sımıfa devam ediyor." demiştir. Çocukların kurgulanmış dünyalarını aktaran hikâyeler ise öğretmen ve annenin gözlemlerini doğrulayacak şekildedir. Çocuklar açık şekillerde okula gidiyor olmanın, öğrenmenin, sınıfın bir üyesi olmanın ve öğretmenlerinin kendi ifadeleri ile "sakin olması, sorular sorması, resim yaparken yardım etmesi, Türkçe öğretmesinin" onları mutlu ettiğini görmemize olanak sağlamıştır. Bu süreçlerin bir parçası olan öğretmen de kendini "Çocukların istekli olmaları insanı mutlu ediyor, daha da işine bağllyor." diyerek ifade etmektedir. Bu hikâyelerde yer alan söylemler, bireylerin birbirlerinin deneyimlerini gözlemledikçe ve birbirlerinin deneyimlerinin bir parçası oldukça, kendilerine ve başka bireylere ilişkin dünyalar kurgulama süreçlerinin değişebilir ve yeniden şekillenebilir olduğunu göstermektedir. Özetle, karşıt hikâyelerin, yani bireylerin mücadele etme, iyileşme, uyum ve çaba gösterme davranışlarının birbirlerine görünür olduğu durumlarda, bireylerin birbirlerinin potansiyellerini ve yetkinliklerini fark ederek kendi eylemlerini de buna göre uyarladıkları anlaşılmaktadır.

Eğitim alanyazınındaki mülteci çalışmaları çoğunlukla aile ve çocukların ihtiyaçları, engelleri ve sorunları gibi hususlara odaklanarak bu bireylerin göç ülkesindeki olumsuz yaşantılarını daha çok ön plana çıkarmaktadır (Baker ve McEnergy, 2005; Strekalova-Hughes ve diğerleri, 2018). Oluşagelen bu alanyazın ise mülteci çocuk ve ailelerin eğitim ihtiyaçlarını karşılama, engeller ve sorunlarla mücadele etme sürecinde gösterdikleri etkin eylemlilik ve yetkinliklerini, dirençlerini ve çözüm odaklı çabalarını, böylelikle güçlü yönlerini göz ardı etmektedir (Wang ve diğerleri, 2019). Bu doğrultuda, mülteci çocuklar ve ailelerin eğitim hizmetlerine erişim süreçlerinde gösterdikleri çaba ve yetkinliklerini görünür kılmak amacıyla başarıları, yapıcılıkları ve güçlü yönlerine dair anlatılmayan hikâyeleri ortaya çıkarmak önemlidir (Ryu ve Tuvilla, 2018; Strekalova-Hughes ve diğerleri, 2017; Wang ve diğerleri, 2019). Bu araştırmanın bulguları da bu minvaldeki yaklaşımlar ile paralel olup mülteci anne ve çocukların EÇE hizmetlerine erişim ve katılım süreçlerinde ortaya koydukları yapıcı eylemlilik ve etkinliklerini yansıtan anlatılmayan hikâyeleri ön plana çıkarmaktadır. Bu araştırma bulguları ile örtüşen nitelikte mülteci aile ve çocukların benzer eylemlilikleri ortaya koyan çalışmaların ilgili alanyazında da mevcut olduğu görülmektedir (Bkz: Puvimanasinghe, Denson, Augoustinos ve Somasundaram, 2014; Ryu ve Tuvilla, 2018; Quadros ve Sarroub, 2016).

Mültecilik deneyiminin beraberinde getirdiği zorlayıcı koşullarla mücadele etmede önemli bir başa çıkma stratejisi, sosyal kaynaklara erişim ve sosyal destek ağlarının genişletilmesidir (El-Khani, Ulph, Peters ve 
Calam, 2018b; Folkman ve Moskowitz, 2004; Gorst-Unsworth ve Goldenberg, 1998). Araştırmalar gerek kendileri gerekse çocukları için kaynak arama, kaynak yaratma ve kaynaklara erişim noktasında eylemlilikler gösteren mülteci kadınların; göç ülkesindeki mültecilik statüsünün getirdiği olumsuz algılardan, yetersizlik beklentilerinden ve var olan potansiyellerini ancak belirli bir noktaya kadar gerçekleştirebileceklerine dair algılarından bağımsız olarak, geniş bir fırsat yelpazesine erişim sağlayıp kendilerinin ve çocuklarının gelişim ve eğitim süreçlerine güçlü katkılar sağlayabildiklerini ortaya koymaktadır (Brewin, Andrews ve Valentine, 2000; McMichael ve Manderson, 2004). Özellikle erken çocukluk döneminde çocuğu olan mülteci kadınlarla yapılan çalışmalarda, okul öncesinden örgün öğretime geçiş sürecinde sosyal kaynakların ve destek mekanizmalarının anneler tarafından etkin kullanılmasının önemi dile getirilmektedir (New, Guilfoyle ve Harman, 2015). Bu araştırma da mülteci kadınların çocukları için bir sosyal kaynak desteği olarak erken çocukluk eğitimi hizmetlerine erişim ve katılım süreçlerinde hem kadın olarak kendilerine dair hem de anne olarak çocuklarına dair kurguladıkları bilinçli, yapıcı, iyimser, yetkin ve güçlü dünyaları yansıtmaktadır. Örneğin, Hikâye 1 ve 2, annelerin kendileri ve çocukları için eğitim kaynakları arama, var olan kaynaklardan yararlanmadan önce kaynağın niteliğini kendisinin veya çocuğunun yüksek yararı için değerlendirme, kaynak kullanımını anlamlı bir etki gözlemleyene kadar sürdürme şeklinde deneyimleri olduğunu göstermektedir. Bu araştırmada olduğu gibi, zorlayıcı koşullarına rağmen göç ülkesinde kendi kişisel dönüşümlerini gerçekleştirmeye çalışan, çocukların eğitimine verdiği önemi ve çabayı önceliklerinden, kendisi ve/veya çocuğu için kurguladığı dünyalardaki hedeflerine ulaşmak adına kaynaklarını harekete geçiren, basmakalıp sığınmacı kadın algısının aksine dirençli, bilinçli ve yetkin mülteci kadınlara dair benzer portreler de alanyazındaki ilgili çalışmalarda görülmektedir (Hoffman, Tierney ve Robertson, 2017; Oo ve Kusakabe, 2010).

Erken çocukluk eğitiminin temelinde tüm çocuklar için önem arz eden okul-aile iş birliğinin mülteci çocuklar özelinde önemi son zamanlarda dile getirilmektedir (Busch ve diğerleri, 2018; Machado-Casas ve diğerleri, 2018; Miller, 2019; Tadesse, 2014). Öğretmenlerin mülteci aileler ile yakından iş birliği yapması ve olumlu okul-aile partnerliği oluşturması çocukların akademik ve sosyal gelişimi için belirleyicidir (Miller, Ziaian ve Esterman, 2018). Bu araştırmada, öğretmenlerin mülteci çocuklara ilişkin kurguladıkları dünyayı şekillendirmede ailelerin önemli roller oynadığı fark edilmiştir. Örneğin, Hikâye 9'da yer aldığı şekliyle annelerin çocukların eğitim sürecine aktif şekilde katkı sağlamak için öğretmenlerden yönlendirme, yardım ve destekleyici kaynaklar talep etmesi ve öğretmenler ile aileler arasındaki karşılıklı etkileşimsel paylaşımların okul ötesinde sosyal mecralara taşınmış olması, öğretmenlerin mülteci ailelere dair algılarını ve mülteci çocuklarla çalışmaya dair tutumlarını olumlu bir zemine çekmiştir. Hikâye 15 'de aktarıldığı üzere, öğretmenler aileler ve çocuklarda gözlemlediği olumlu tutumların mesleki tatmin ve bağlılıklarını kuvvetlendirdiğini açık şekillerde ifade etmişlerdir. Bu doğrultuda, başka çalışmalarda da bulunduğu üzere, mülteci aileler ve çocuklar özelinde, öğretmen-anne iş birliği ve olumlu fikir alışverişlerinin öğretmenlerin mesleki adanmışlıklarını güçlendirdiği söylenebilir (Kroeger ve diğerleri, 2019).

$\mathrm{Bu}$ araştırmanın bulguları, anne ve öğretmen ya da eğitim uygulayıcılardan başka, çocukların da kendilerine dair dünyaların kurguladıklarını yansıtmaktadır. Hikâye 16, 17 ve 18'de sesi duyulan birçok çocuğun, göç ülkesinde sosyal-duygusal yönden iyileşme sürecinde olduğu görülmektedir. Çocukların, zorlayıcı koşullarına rağmen gerek sosyal uyum gerekse akademik yetkinlik açısından direnç, çaba ve başarı göstererek, çeşitli eylemlilikler sergileyerek günlük yaşantılarını yönlendirip geleceğe dair gerçekçi ve umut dolu hayaller edindikleri ve hedef odaklı planlamalar yaptıkları anlaşılmaktadır. Mülteci çocukları "mağdur", "kırılgan", "yetersiz" ve "eksik" bir bakış açısıyla değerlendirmekten ziyade "güçlü", "yapıcı" ve "başarılı" yönleriyle ortaya çıkaran bu araştırmadaki hikâyelerin, kamplarda yaşayan mülteci çocukların geleceğe dair beklentileri ve başarı öyküleriyle benzer olduğu görülmektedir (Arvanitis ve diğerleri, 2019). Bazı çalışmalarda yer aldığı şekliyle, çocuklar kendilerine ilişkin kurguladıkları dünyalarda çoğunlukçu söylemlerde var olan "öteki", "zayıf" ve "geleceği belirsiz" bir kimliğe sahip bireylerden ziyade (Ludwig, 2016) "güçlü", "umutlu" ve "sosyal-akademik açıdan yetkin" kimliklerle kendilerini kurgulamaktadırlar. Bu araştırma bulgularının işaret ettiği üzere mülteci çocukların bu tür olumlu deneyimler ve kimlikler edinmesinin ön koşullarından biri, çocukların öğrenmeyi ve sosyalleşmeyi destekleyici uygun koşullar ve 
ortamlar ile çevrelenmesidir. Örneğin, bu araştırmadaki hikâyeler, çocuğun kültür ve dilinin gözetildiği bir eğitim yaklaşımın benimsendiği sınıf ikliminde, çocukların akademik ve sosyal-duygusal yetkinliklerinin ortaya çıktığını ve çeşitli beceriler edinerek bu becerileri ev ve mahalle hayatı gibi okul dışı ortamlara taşıyabildiklerini yansıtmaktadır. Alanyazındaki benzer çalışmalar da mülteci çocukların var olan güçlü potansiyellerini gerçekleştirebilmeleri için ihtiyaca yönelik ve çocukların kültürüne duyarlı ve güçlü yönlerini desteklemeye odaklanan programlarının etkili olduğunu göstermektedir (Cho ve diğerleri, 2019; Daniel, 2019; Erdemir, 2019; Strekalova-Hughes ve Wang, 2019).

Özetle, bütüncül olarak değerlendirildiğinde, bu araştırmanın bulguları, mülteci ailelerin ve çocukların kendileriyle özdeşleştirilen "mağdur", "eksik", "yetersiz", “örselenebilir", "ilgisiz” gibi çağrışımlara karşı bir söylem geliştiren kimliklere sahip olduklarını göstermektedir. Aile ve çocukların güçlü yanlarına, yetkinliklerine ve az bilinen çaba ve eylemliliklerine odaklanıldığında benzer karşıt hikâyelerin varlığı keşfedilebilir. Ulusal alanyazında mülteci aile ve çocukların anlatılmayan karşıt hikâyelerini temel alan çalışmaların olmadığı görülmekle beraber bu araştırmanın ilgili alanyazına ulusal boyutta katkı sağlayacağı düşünülebilir. Mevcut çalışmaların çoğunluğu mültecilik deneyimini, ailelere ve çocuklara bizzat ses ve yetkinlik vermeden, öğretmenlerin görüşleri üzerinden ele almaktadır. Bu çalışmalar genellikle öğretmenlerin mülteci çocukların eğitimini desteklemede kendilerini yeterli hissetmedikleri ve sınıf uygulamalarını mülteci çocuklara yönelik düzenlemekte zorluklar yaşadığını göstermektedir (Kardeş ve Akman, 2018; Sağlam ve İlksen-Kanbur, 2017; Mercan-Uzun ve Bütün, 2017). Öğretmenlerin/eğitim uygulayıcıların yaşadıkları bu güçlükler düşünüldüğünde, mülteci çocuklar ve aileler ile çalışmaya ilişkin "olumsuz" veya "zorluklarla dolu" dünyalar kurgulayabilecekleri öngörülebilir. Bu doğrultuda olumlu, güçlü ve başarı örneklerinin, bir diğer deyişle anlatılmayan karşıt hikâyelerin ön plana çıkarılması, araştırmalar ve öğretmen eğitimleri yoluyla öğretmenlere sorulması ve onlara duyulur kılınması önemlidir.

\section{Sonuç ve Öneriler}

Özetle, yapılmış olan bu araştırmada Türkiye'de yaşamaya başlamış Suriyeli mülteci aile ve çocukların eğitim ekseninde edindikleri deneyimler ele alınmış; aile ve çocukların mülteci kimliğinin ötesinde geçmişten getirerek sahip oldukları ve Türkiye'de yeni bir yaşam inşa etme sürecinde edindikleri yeni kimlikler, bireylerin güçlü yönleri, yarattıkları olanaklar ve mücadeleleri fark edilerek incelenmiştir. Çalışma bulgularından en temeli, aile ve çocukların eğitime ve eğitim olanaklarına verdiği değeri ortaya koyarken, çalışmanın önemli bulgularından biri de mülteci bireylerin, özellikle erken çocukluk dönemindeki küçük çocukların iyileşme, direnç ve uyum gösterdikleri ve eylemlilik sergileyerek günlük yaşantılarını yönlendirip geleceğe dair gerçekçi bir o kadar da umut dolu hayallere sahip olmalarıdır. Kurgulanmış dünyalar kuramının da (Holland ve diğerleri, 1998) öngördüğü üzere, bireylerin tüm bu süreçlerdeki yaşantılarında, kimliklerinin çevrelerindeki diğer bireyler ile (aile, çocuk, diğer mülteci bireyler ve eğitimciler gibi) karşılıklı etkileşim yarattıkları ilişkiler silsilesi yoluyla bir devinim içerisinde şekillendiği de görülmüştür.

Bu araştırmanın temel önerilerinden biri, mülteci bireylerin yaşantılarını araştıran bilimsel çalışmalarda, bireylerin deneyimlerine bütüncül bir bakış açısı ile, bir diğer deyişle bireylerin yaşantılarındaki karşıt hikâyelere de kulak vererek yaklaşılması gerektiğidir. Şüphesiz ki mültecilik deneyimi ve statüsü, bireylerin yaşantılarına yıkıcı kayıplar, derin olumsuz deneyimler getirmekte sonrasında ise göç ülkesinde var olan yapısal engeller, ulusal ve uluslararası politik uygulamalar ve toplumsal önyargılar kişilerin yaşamları üzerinde olumsuz etkiler yaratmaya devam edebilmekte, mülteci bireyler temel yaşam haklarından dahi mahrum olabilmektedirler. Mülteci bireylerin eğitime ilişkin deneyimlerini ele alan bilimsel çalışmalarda, onları çevreleyen bu olumsuz durumların göz önüne alınması ile birlikte, mültecilerin araştırmalarda nasıl konumlandığına da hassasiyet ile yaklaşılmalı ve onlara ilişkin toplumda süregelen peşin hükümler ve olumsuz söylemlere istemsiz katkıda bulunmanın önüne geçilmelidir. Bu noktada, karşıt hikâyeler bakış açısı faydalı bir yöntem olabilir. Karşıt hikâyeler, mülteci bireylerin yaşadıkları zorlukları göz ardı etmemizi değil, bu zorlukların kaynağında bireylerin bizzat kendilerinden ziyade onları çevreleyen toplumsal, ekonomik ve siyasi dinamiklerin olduğunu daha net görebilmemizi sağlar (Urrieta, 2007). Bununla birlikte, mülteci bireyleri yaşadıkları zorluklar ve güçlü yönleri ile daha bütünsel şekilde anlayabilmemizi mümkün kılar. Bu tür bir 
çaba hem bilimsel araştırma sorumluluğu hem de etik bir sorumluluktur.

Bu araştırma sonuçlarından doğan bir diğer öneri de mülteci bireylere ilişkin bu makalede yer alan benzer hikâyelerin yaygınlaştırılması gerekliliğidir. Öğretmen eğitimi çıtılarına odaklanılır ise, eğitim hizmetlerine erişim ve bu hizmetlerden faydalanma sürecinde, mülteci çocuklar ve ailelerin gerek yerel inisiyatifler gerekse bireysel inisiyatifleri sonucu edindikleri olumlu deneyimleri, ve böylece anlatılmayan hikâyeleri keşfetmek ve bu hikâyelere ses vermek, mülteci bireylere ilişkin olumsuz varsayımların ve algıların sarsılması için, özellikle de mülteci çocuklarla çalışacak erken çocukluk eğitimcileri için önemli ve yapıcı bir adım olarak değerlendirilebilir. Mevcut durumda, Türkiye'de var olan ve giderek artan kültürel çeşitlilik göz önünde bulundurulduğunda, eğitim fakülteleri bünyesinde bu tür diyaloglara yer açabilecek Çokkültürlü Eğitim ya da Kapsayıcı Eğitim odaklı derslerin olmaması bir eksiklik olarak görülmektedir. Bununla birlikte, Topluma Hizmet Uygulamaları, Aile Katılımı ve Öğretmenlik Uygulaması gibi derslerde, mülteci öğrenci ve ailelerin güçlü yönlerine vurgu yapan uygun yönlendirmeler ile öğretmen adayları mülteci çocukların yoğun olduğu okullarda çalışmalarda bulunabilirler. Bu tür uygulamalar, öğretmen adaylarında farkındalık yaratma ve onlara deneyim kazandırma açısından anlamlı olabilir. Millî Eğitim Bakanlığı tarafından sunulan ve yaygınlaşan mülteci çocukların eğitimine ilişkin hizmet içi öğretmen eğitimlerinde de benzer şekillerde karşıt hikâyeleri öğretmenler ile paylaşmak ve öğretmenlerden karşıt hikâyeleri dinlemek, bir bakış açısı sağlayarak alternatif aile katılımı uygulamaları geliştirme ve mülteci çocuktan beklentiyi şekillendirme konularında öğretmenlere yardımcı olabilir.

$\mathrm{Bu}$ çalışmanın sınırlılıklarına odaklanırsak, makalede ele alınmış bilimsel araştırma ve projeler kapsamında gerçekleştirilen proje etkinliklerine tüm aile üyeleri davet edilmesine rağmen annelerin diğer aile üyelerine göre katılımı daha yüksek olmuş, araştırmacılar, öğretmenler/eğitim uygulayıcıları ile iletişime geçen aile üyeleri de sıklıkla anneler olmuştur. Bu durumun farklı sebepleri olabilir. Örneğin, çocukların eğitim ve bakım sorumluluğunu annelerin diğer aile üyelerine göre daha çok üstlenmiş olması, babaların yoğun çalışma saatleri sebebiyle etkinlik ve uygulamalarda varlık göstermemeleri, ya da baba ve diğer aile üyelerinin kaybı ya da başka ülkede yaşıyor olması gibi. Bu sebeple, makalede mülteci aile kavramı daha çok anneler üzerinden ele alınmış, diğer aile üyelerinin hikâyelerine erişim sağlanamamıştır. Bir diğer sınırlılık ise, bu makalede paylaşılan tüm çalışmalarda yer alan aile ve çocuklar Türkiye'de eğitim olanaklarına bir şekilde erişim sağlayabilmiş bireylerden oluşmaktadır. Mevcut durumda, mülteci çocuk nüfusunun ancak yarısının devlet okullarına devam edebildiği göz önüne alınmalı ve bu olanağa erişememiş diğer aile ve çocukların yaşamlarında ne tür hikâyelerin olduğu araştırmalıdır. Son olarak, bu araştırma kapsamında ele alınan karşıt hikâyeler araştırmacıların daha önce yapmış oldukları çalışmalarda yer almış hikâyelerin analiz edilmesi ile gerçekleştirilmiştir. İleride yapılacak araştırmalar retrospektif olmaktan ziyade, mülteci bireylerin kurgulanmış dünyalarını ve karşıt hikâyelerini keşfetme amacı ile planlanırsa, bizlere onların Türkiye'deki eğitim deneyimleri adına daha zengin ve derinlikli bir veri seti sunabilir.

Bilgilendirme: $\mathrm{Bu}$ makale kapsamında yapılan araştırma, yazarların yürütücü ya da araştırmacı olarak gerçekleştirdiği, Türkiye'de yaşayan Suriyeli çocuk ve ailelerin eğitim özelinde yaşam deneyimlerini konu alan ve farklı sorulara cevap arayan aşağıdaki proje ve araştırmaların veri setleri bir araya getirilerek, karşıt hikayelerin ortaya çıkarılması ve analiz edilmesi ile gerçekleştirilmiştir.

- Becoming the Teacher of a Refugee Child: Teachers' Evolving Experiences in Turkey başlıklı çalışma Dr. Elif Karslı Çalamak ve Dr. Sultan Kılınç'ın ortak yürüttüğü bir bilimsel araştırmadır.

- Building Bridges in Education: Syrian Children and Families in Turkey's School System Projesi (S-TU-15015-GR-041) Amerika Birleşik Devletleri Ankara Büyükelçiliği tarafından desteklenmiştir.

- GÖÇ-MAT: Göçmen Çocuklar ile Çalışan Öğretmenlerin Matematik Eğitimi Özelinde Mesleki Niteliklerinin Geliştirilmesi projesi (215K478) Türkiye Bilimsel ve Teknolojik Araştırma Kurumu (TÜBİTAK) tarafından desteklenmiştir.

- Next Generation Teachers Co-Working for Refugee and Immigrant Communities in Turkey and Ireland projesi 
Amerika Birleşik Devletleri, Dışişleri Bakanlığı tarafından desteklenmiştir.

- Suriyeli Çocuklar için Yaz Anaokulları projesi Anne Çocuk Eğitim Vakfı (AÇEV) tarafından gerçekleştirilip Siemens Türkiye ve Plan International tarafından desteklenmiştir.

- Suriyeli ve Türk Çocuklar için Uçan Kütüphane projesi Goethe-Institut İstanbul tarafından gerçekleştirilip Federal Almanya Dışişleri Bakanlığı tarafından desteklenmiştir.

- Suriyeli ve Türk Çocuklar için Yaratıcılık Zamanı projesi Goethe-Institut İstanbul tarafından gerçekleştirilip Federal Almanya Dışişleri Bakanlığı tarafından desteklenmiştir.

- Suriyeli ve Türk Gençler için Futbol Birleştirir! projesi Goethe-Institut İstanbul tarafından gerçekleştirilip Federal Almanya Dışişleri Bakanlığı tarafından desteklenmiştir.

\section{Kaynaklar}

Allexsaht-Snider, M. (2006). Editorial: Urban parents' perspectives on children's mathematics learning and issues of equity in mathematics education. Mathematical Thinking and Learning, 8(3), 187-195.

Allexsaht-Snider, M., Vazquez Dominguez, M., Buxton, C. ve Karsl, E. (2017). Figured worlds of immigrant fathers, sons, and daughters in steps to college through science bilingual family workshops. Gender $\mathcal{E}$ Education. Elektronik ön bask1. https://doi.org/10.1080/09540253.2017.1343936

Arvanitis, E., Yelland, N. J. ve Kiprianos, P. (2019). Liminal spaces of temporary dwellings: Transitioning to new lives in times of crisis. Journal of Research in Childhood Education, 33(1), 134-144.

Beiser, M. (2009). Resettling refugees and safeguarding their mental health: Lessons learned from the Canadian Refugee Resettlement Project. Transcultural Psychiatry, 46(4), 539-583.

Baker, P. ve McEnery, T. (2005). A corpus-based approach to discourses of refugees and asylum seekers in UN and newspaper texts. Journal of Language and Politics, 4(2), 197-226.

Bekman, S. (1998). Eşit firsat: Anne-Çocuk Eğitim Programı'nın değerlendirilmesi. İstanbul: Anne-Çocuk Eğitim Vakfı Yayınları.

Birleşmiş Milletler Mülteciler Yüksek Komiserliği. (2019). Syria regional refugee response. 24 Mart 2019 tarihinde https://data2.unhcr.org/en/situations/syria adresinden erişildi.

Boutte, G. S. ve T. O. Jackson. (2014). Advice to white allies: Insights from faculty of color. Race, Ethnicity, and Education, 17(5), 623-642.

Brewin, C. R., Andrews, B. ve Valentine, J. D. (2000). Meta-analysis of risk factors for posttraumatic stress disorder in trauma-exposed adults. Journal of Consulting and Clinical Psychology, 68(5), 748-766.

Bronfenbrenner, U. (1979). The ecology of human development. Cambridge: Harvard Üniversitesi Yayınları.

Busch, J., Bihler, L. M., Lembcke, H., Buchmüller, T., Diers, K. ve Leyendecker, B. (2018). Challenges and solutions perceived by educators in an early childcare program for refugee children. Frontiers in Psychology, 9, 1-10.

Calabarse Barton, A., Drake, C., Perez, J. G., St. Louis, K. ve George, M. (2004). Ecologies of parental engagement in urban education. Educational Researcher, 33(4), 3-12.

Cho, H., Wang, X. C. ve Christ, T. (2019). Socio-emotional learning of refugee English language learners in early elementary grades: Teachers' perspectives. Journal of Research in Childhood Education, 33(1), 40-55.

Clandinin, D. J. ve Connelly, F. M. (2000). Narrative inquiry: Experience and story in qualitative research. San Francisco: Jossey-Bass.

Castro-Salazar, R. ve Bagley, C. (2010). 'Ni de aquí ni from there'. Navigating between contexts: Counternarratives of undocumented Mexican students in the United States. Race Ethnicity and Education, 13(1), 2340 . 
Chung, H. (2013). Korean temporary migrant mothers' conceptualization of parent involvement in the United States. Asia-Pacific Journal of Education, 33(4), 461-475.

Collins, P. H. (1994). Shifting the center: Race, class, and feminist theorizing about motherhood. E. N. Glenn, G. Chang ve L. R. Forcey (Editörler), Mothering: Ideology, experience and agency içinde (s. 45-66). New York: Routledge.

Cote, J. E. ve Levine, C. G. 2002. Identity formation, agency, and culture: A social psychological synthesis. Mahwah, NJ: Erlbaum.

Critelli, F. M. (2015). Parenting in a new land: Specialized services for immigrant and refugee families in the USA. Journal of International Migration and Integration, 16(4), 871-890.

Çelik, Ç. ve İçduygu, A. (2018). Schools and refugee children: The case of Syrians in Turkey. International Migration, 57(2), 253-267.

Daniel, S. M. (2019). Writing our identities for successful endeavors: Resettled refugee youth look to the future. Journal of Research in Childhood Education, 33(1), 71-83.

Dantas, M. L. ve Manyak, P. C. (Ed.). (2010). Home-school connections in a multicultural society: Learning from and with culturally and linguistically diverse families. New York, NY: Routledge.

Delgado-Gaitan, C. (1991). Involving parents in the schools: A process of empowerment. American Journal of Education, 100, 20-46.

Durand, T. M. (2011). Latina mothers' cultural beliefs about their children, parental roles, and education: Implications for effective and empowering home-school partnerships. Urban Review, 43(2), 255-278.

Dybdahl, R. (2001). Children and mothers in war: An outcome study of a psychosocial intervention program. Child Development, 72(4), 1214-1230.

Eğitim Reformu Girişimi. (2019). Eğitim izleme raporu 2017-18. 21 Mart 2019 tarihinde http://www.egitimreformugirisimi.org/wp-content/uploads/2017/03/EIR_2017_2018_29.11.18.pdf adrresinden erişildi.

Elenes, C. A., Gonz.lez, F. E., Delgado-Bernal, D. ve Villenas, S. (2001). Introduction: Chicana/Mexicana feminist pedagogies: Consejos, respeto, y educacion in everyday life. International Journal of Qualitative Studies in Education, 14(5), 595-602.

El-Khani, A., Ulph, F., Peters, S. ve Calam, R. (2018a). Syria: Refugee parents' experiences and need for parenting support in camps and humanitarian settings. Vulnerable Children and Youth Studies, 13(1), 19-29.

El-Khani, A., Ulph, F., Peters, S. ve Calam, R. (2018b). Syria: Coping mechanisms utilized by displaced refugee parents caring for their children in pre-resettlement contexts. Intervention, 15(1), 34-50.

Emerson, R. M., Fretz, R. I. ve Shaw, L. L. (2001). Participant observation and fieldnotes. P. Atkinson, A. Coffey, S. Delamont, J. Lofland, ve L. Lofland (Editörler), Handbook of ethnography içinde (s. 352-368). London, UK: Sage.

Erdoğan, M. M. (2016). Eğitim izleme raporu 2015-2016. Eğitim Reformu Girişimi.

Erdemir, E. (2019). Effects of summer preschools on Syrian and Turkish children: Assessment report. İstanbul: AnneÇocuk Eğitim Vakfı.

Erdemir, E. (2017a, Ağustos). Summer preschool intervention program for Syrian refugee children: Language proficiency and socioemotional gains. 27. Uluslararası Avrupa Erken Çocukluk Eğitimi Araştırmaları Derneği Kongresi (EECERA), Bolonya, İtalya.

Erdemir, E. (2017b, Ekim). Suriyeli çocuklar için yaz anaokulları programı: Pilot müdahale çalışması. 5. Uluslararası Okul Öncesi Eğitim Kongresi (IECEC/UOEK), Gazi Üniversitesi, Ankara. 
Erdemir, E., Diri, A., Büyükabacı, S. Ö. ve Kaya, M. U. (2018, Eylül). GAP Yaz Anaokullarının Suriyeli ve Türk çocukları üzerindeki etkileri. 3. Uluslararası Çocuk Koruma Kongresi, Ordu, Türkiye.

Erickson, F. (1992). Ethnographic microanalysis of interaction. M. LeCompte, W. Millroy, ve J. Preissle (Editörler), The handbook of qualitative research in education içinde (s. 201-225). San Diego: Akademik Yayınlar.

Folkman, S. ve Moskowitz, J. T. (2004). Coping: Pitfalls and promise. Annual Review of Psychology, 55, 745-774.

Georgis, R., Gokiert, R. J., Ford, D. M. ve Ali, M. (2014). Creating inclusive parent engagement practices: Lessons learned from a school community collaborative supporting newcomer refugee families. Multicultural Education, 21(3/4), 23.

Gonzalez, N., Moll, L. C. ve Amanti, C. (2005). Funds of knowledge: Theorizing practices in households and classrooms. Mahwah, NJ: Erlbaum.

Gorst-Unsworth, C. ve Goldenberg, E. (1998). Psychological sequelae of torture and organized violence suffered by refugees from Iraq. Trauma related factors compared with social factors in exile. The British Journal of Psychiatry, 172(1), 90-94.

Göç İdaresi Genel Müdürlüğü. (2019). Göç istatistikleri: Geçici koruma. 24 Mart 2019 tarihinde http://www.goc.gov.tr/icerik3/gecici-koruma_363_378_4713 adresinden erişildi.

Delgado-Gaitan, C. (2005). Family narratives in multiple literacies. Anthropology \& Education Quarterly, 36(3), 265-272.

Hoffman, S. J., Tierney, J. D. ve Robertson, C., L. (2017). Counter-narratives of coping and becoming: Karen refugee women's inside/outside figured worlds. Gender, Place \& Culture, 24(9), 1346-1364.

Hong, S. (2011). A cord of three strands: A new approach to parent engagement in schools. Cambridge, MA: Harvard Eğitim Yayınları.

Holland, D. C., Lachicotte, W., Skinner, D. ve Cain, C. (1998). Identity and agency in cultural worlds. Cambridge, MA: Harvard Üniversitesi Yayınları.

Howard, J., Thompson, C., Nash, K. ve Rodriguez, S. (2016). Missing stories: The messy processes, multifaceted risks, and multiple roles of critical ethnographers. Critical Questions in Education, 7(3), 302-324.

Hsin, C.-T. (2011). Active agents: The new-immigrant mothers' figured worlds of home literacy practices for young children in Taiwan. The Asia-Pacific Education Researcher, 20(1), 17-34.

Ingleby, D. ve Watters C. (2002). Refugee children at school: Good practices in mental health and social care. Education and Health, 20(3), 43-45.

İnsan Hakları İzleme Örgütü (2015). "Geleceğimi hayal etmeye çalıştı̆̆ımda hiçbir şey göremiyorum": Türkiye'deki Suriyeli mülteci çocukların eğitime erişiminin önündeki engeller-Kayıp nesil olmalarını önlemek. 24 Mart 2019 tarihinde https://www.hrw.org/sites/default/files/report_pdf/turkey1115tu_web.pdf adresinden erişildi.

Karan, Ş. ve Erdemir, E. (2019, Haziran). Çocuğun öznel iyi olma hali: Okul. 6. Uluslararası Avrasya Eğitim Araştırmaları Kongresi (EJER), Ankara Üniversitesi, Ankara.

Kardeş, S. ve Akman, B. (2018). Suriyeli sığınmacıların eğitimine yönelik öğretmen görüşleri. Illköğretim Online, $17(3), 1224-1237$.

Karslı-Çalamak, E. (2018). Syrian mothers producing counter stories in co-constructed school spaces: Rethinking the role of schools in engaging refugee families. European Education, 50(1), 42-57.

Karsl1-Çalamak, E., Tuna, M.E. ve Allexsaht-Snider, M. (2019, Nisan). Uncovering refugee families' educational efforts through multilingual family math workshops. Amerikan Eğitim Araştırmaları Derneği Kongresi (AERA), Toronto, Kanada. 
Kayumova, S., Karslı, E., Allexsaht-Snider, A. ve Buxton, C. (2015). Latina mothers and daughters: Ways of knowing, being, and becoming in the context of bilingual family science workshop. Anthropology $\mathcal{E}$ Education Quarterly, 46(3), 260-276.

Kolano, L. Q. ve Davilla, L. T. (2019). Transforming learning of refugee girls within a community youth organization serving Southeast Asians in North Caroline. Journal of Research in Childhood Education, 33(1), 119-133.

Kroeger, J., Mariyam, M. ve McTeer, J. S. (2019). Countering the misguided interpretations of fashion shows and thug life: A material-cultural analysis of Hmong father and son's experience in school(s). Journal of Research in Childhood Education, 33(1), 22-39.

Ladson-Billings, G. ve Tate, W. (1995). Toward a critical race theory of education. Teachers College Record, 97, $47-68$.

Lareau, A. (2003). Unequal childhoods: Class, race, and family life. Berkeley, CA: California Üniversitesi Yayınları.

Lawrence-Lightfoot, S. (1978). Worlds apart. New York: Basic Books Yayıncllı.

Leontiev, A. N. (1978). Activity, consciousness and personality. Englewood Cliffs, NJ: Prentice Hall.

Ludwig, B. (2016). The different meanings of the word refugee. E. Feuerherm ve V. Ramanathan (Editörler), Refugee resettlement in the United States: Language, policy, pedagogy içinde (s. 35-53). Bristol: Multilingual Matters.

Machado-Casas, M., Andrés Cabello, S., Talati-Espinza, K. ve Abdul-Razaq, H. (2018). Working with immigrant and refugee families: broadening cross-cultural understanding with immigrant/refugee families. Foro de Educación, 16(25), 193-205.

Maxwell, J. A. ve Miller, B. A. (2008). Categorizing and connecting strategies in qualitative data analysis. S. N. Hesse-Biber, S. Nagy ve P. Levy (Editörler), Handbook of emergent methods içinde (s. 461-477). New York, NY: Guilford Yayınları.

Mercan-Uzun, E. M. ve Bütün, E. (2016). Okul öncesi eğitim kurumlarındaki Suriyeli sığınmacı çocukların karşılaştıkları sorunlar hakkında öğretmen görüşleri. Uluslararası Erken Çocukluk Eğitimi Çalışmaları Dergisi, 1(1),72-83.

McMichael, C. ve Manderson, L. (2004). Somali women and well-being: Social networks and social capital among immigrant women in Australia. Human Organization, 63(1), 88-99.

Milli Eğitim Bakanlığı [MEB] (2018). Mutlu çocuklar güçlü Türkiye: 2023 eğitim vizyonu. 1 Mart 2019 tarihinde http://2023vizyonu.meb.gov.tr/ adresinden erişildi.

Milli Eğitim Bakanlığı [MEB Hayat Boyu Öğrenme Genel Müdürlüğü Göç ve Acil Durum Eğitim Daire Başkanlığı]. (2019). Geçici koruma kapsamı altındaki öğrencilerin eğitim hizmetleri. 26 Mart 2019 tarihinde https://hbogm.meb.gov.tr/meb_iys_dosyalar/2019_03/06145652_04-Mart2019_internetsunu.pdf adresinden erişildi.

Miller, A. L. (2019). (Re)conceptualizing family-school partnerships with and for culturally and linguistically diverse families. Race Ethnicity and Education. İlk dijital basım.

Miller, E., Ziaian, T. ve Esterman, A. (2018). Australian school practices and the education experiences of students with a refugee background: A review of the literature. International Journal of Inclusive Education, 22(4), 339-359.

Morrison, J., Pikhart, H. ve Goldblatt, P. (2017). Interventions to reduce inequalities in health and early child development in Europe from a qualitative perspective. International Journal for Equity in Health, 16(87), 19. 
New, R., Guilfoyle, A. ve Harman, B. (2015). Children's school readiness: The experiences of African refugee women in a supported playgroup. Australasian Journal of Early Childhood, 40(1), 55-62.

Oo, Z. M. ve K. Kusakabe. (2010). Motherhood and social network: Response strategies of internally displaced Karen women in Taungoo district. Women's Studies International Forum, (33) 482-491.

Özer, S., Şirin, S. ve Oppedal, B. (2013). Bahçeşehir study of Syrian refugee children report. 13 Nisan 2019 tarihinde https://www.fhi.no/globalassets/dokumenterfiler/studier/ungkul/bahcesehir-study-report.pdf sayfasından erişildi.

Polkinghorne, D. E. (1995). Narrative configuration in qualitative Analysis. A. Hatch ve R. Wisniewski (Editörler), Life history and narrative kitabında (s. 5-23). London: Falmer Yayınları.

Puvimanasinghe, T., Denson, L. A., Augoustinos, M. ve Somasundaram, D. (2014). “Giving back to society what society gave us": Altruism, coping, and meaning making by two refugee communities in South Australia. Australian Psychologist, 49, 313-321.

Quadros, S. ve Sarroub, L. K. (2016). The case of three Karen refugee women and their children: Literacy practices in a family literacy context. Diaspora, Indigenous, and Minority Education, 10(1), 28-41.

Richmond, H. J. (2002). Learners' lives: A narrative analysis. The Qualitative Report, 7(3), 1-14.

Ryu, M. ve Tuvilla, M. R. S. (2018). Resettled refugee youths' stories of migration, schooling, and future: Challenging dominant narratives about refugees. The Urban Review, 50(4), 1-20.

Sağlam, H. İ. ve İlksen-Kanbur, N. (2017). Sınıf öğretmenlerinin mülteci öğrencilere yönelik tutumlarının çeşitli değişkenler açısından incelenmesi. Sakarya University Journal of Education, 7(2), 310-323.

Sampson, R. C. (2016). Caring, contributing, capacity building: Navigating contradictory narratives of refugee settlement in Australia. Journal of Refugee Studies, 29(1), 98-116.

Solorzano, D. G. ve Yosso, T. (2002). Critical race methodology: Counter-story-telling as an analytical framework for education research. Qualitative Inquiry, 8(1), 23-44.

Strekalova-Hughes, E., Nash, K. ve Erdemir, E. (2018, Nisan). Refugee critical race theory in education: An emerging ontological and epistemological lens. Amerikan Eğitim Araştırmaları Derneği Kongresi (AERA), New York, Amerika.

Strekalova-Hughes, E., Nash, K. ve Erdemir, E. (2017, Ekim). Toward a refugee critical race theory in education. 25. Uluslararası Erken Çocukluk Eğitimini Yeniden Kavramsallaştırma Kongresi (RECE), Toronto, Kanada.

Strekalova-Hughes, E. ve Wang, X. C. (2019). Perspectives of children from refugee backgrounds on their family storytelling as a culturally sustaining practice. Journal of Research in Childhood Education, 33(1), 6-21.

Tadesse S. (2014). Parent involvement: perceived encouragement and barriers to African refugee parent and teacher relationships. Childhood Education, 90, 298-305.

Tyeklar, N. (2016). The US refugee resettlement process: A path to self-sufficiency or marginalization. E. Feuerherm ve V. Ramanathan (Editörler), Refugee resettlement: Language, policy, pedagogy içinde (s. 152171). Bristol: Multilingual Matters.

Turney, K. ve Kao, G. (2009). Barriers to school involvement: Are immigrant parents disadvantaged? The Journal of Educational Research, 102(4), 257-271.

Urrieta, L. (2007). Figured worlds and education: An introduction to the special issue. Urban Review, 39(2), $107-116$.

Uyan-Semerci, P. ve E. Erdoğan (2018). Who cannot access education? Difficulties of being a student for children from Syria in Turkey. Vulnerable Children and Youth Studies, 13(1), 30-45. 


\section{Elif KARSLI ÇALAMAK \& Ersoy ERDEMIR}

Valdes, G. (1996). Con respeto: Bridging the distance between culturally diverse families and schools: An ethnographic portrait. New York: Teachers College Yayınları.

Vygotsky, L. S. (1978). Mind in society: The development of the higher psychological processes. Cambridge, MA: Harvard Üniversitesi Yayınları.

Yosso, T. (2006). Critical race counter-stories along the Chicana/Chicano educational pipeline. New York: Taylor \& Francis.

Yıldırım, A. ve Şimşek, H. (2018). Sosyal bilimlerde nitel araştırma yöntemleri (11. bs.). Ankara: Seçkin Yayıncılık.

Wang, X. C., Strekalova-Hughes, E. ve Cho, H. (2019). Going beyond a single story: Experiences and education of refugee children at home, in school, and in the community. Journal of Research in Childhood Education, $33(1), 1-5$.

Villenas, S. (2005). Between the telling and the told: Latina mothers negotiating education in new borderlands. J. Phillion, M. F. He, ve F. M. Connelly (Editörler), Narrative and experience in multicultural education içinde (s. 71-91). Thousand Oaks, CA: Sage. 
Türkiye'de Yaşayan Suriyeli Çocuklar...

\section{EXTENDED ABSTRACT}

\section{Introduction}

The aim of this research was to investigate the counter narratives of Syrian refugee families and children living in Turkey as reflective of their experiences in accessing and participating in early childhood education services. Agents of the counter narratives were refugee families and children living in different cities in Turkey. Drawing on the Figured Worlds theory (Holland, Lachicotte, Skinner \& Cain, 1998), we explored the agency of families and children in various counter narratives, in particular, their practices of coping, recovery, resilience and competence in relation to education experiences along with searching for and creating relevant resources. The study portrays and interprets counter narratives in which families and children figured out different worlds, thus identities, in relation to themselves and other immediate actors in their lives. The following research questions guided the study: (1) What are the counter narratives, which reflect the experiences of Syrian refugee families and children living in Turkey, with respect to their access and participation in early childhood services? (2) What do Syrian refugee families' and children's counter narratives reflect about their processes of figuring their identities? This study builds on and extends the previous relevant research which recognizes and acknowledges the agency and strength of refugee families and children (e.g., Oo \& Kusakabe, 2010; Ryu \& Tuvilla, 2018; Quadros \& Sarroub, 2016; Wang, Strekalova-Hughes \& Cho, 2019).

\section{Method}

As a methodological approach, in this research we draw on counter-narratives, which mainly refer to the historically marginalized communities' stories that talk back to widespread conventional and deficit perspectives (Solorzano \& Yosso, 2002). The raw data set of the research, which we pulled out the counter narratives from, are composed of eight different research and community service projects carried out by the two authors since 2015. These eight different research and community projects shared three common overarching goals: 1 ) investigating the educational experiences of Syrian refugee children and families; 2 ) and teachers from both Turkey and Syria who are living in Turkey; and 3) creating support mechanisms for refugee children and families in the country. We conducted these projects across the country in the cities of Ankara, Gaziantep, Mardin, Hatay, İstanbul and Şanlıurfa. The distinguishing characteristics of the participants in the projects are as follows: (1) Refugee children from Syria who are in early childhood period and mainly between the ages of 4 to 9. (2) Refugee families from Syria, majority of whom are mothers (3) Public school teachers in Turkey who have a high number of refugee students in their classrooms (4) Volunteer teachers from Turkey or Syria who work for educational intervention services offered by various non-profit governmental organizations.

These eight projects followed qualitative research traditions, particularly educational-ethnographic approaches (Erickson, 1992). In these projects, we collected data from families, children and educators through observational notes, semi-structured interviews, and field notes which included our personal reflections of the research processes (Emerson, Fretz \& Shaw, 2001). In relation to the two research questions shared above, we first determined the counter narratives out of the large data sets. This process was guided by the five elements of Critical Race theory (Ladson-Billings \& Tate, 1995), which are included in stories in order to conceptualize them as counter narratives (Solorzano \& Yosso, 2002). At the end of this process, a total number of 32 counter narratives were selected and then analyzed systematically in an in-depth fashion through narrative analysis method (Polkinghorne, 1995; Richmond, 2002).

\section{Results}

Analyses indicated two major categories under which counter narratives emerge with their various respective sub-categories. The first category of Mother's figured worlds included two sub-categories: (1) Mothers' figured worlds of themselves, and (2) Mothers' figured worlds of other refugee mothers. The second category of figured worlds in regards to children included three subcategories: (1) Mothers' figured worlds of their children, (2) Teachers' figured worlds of children, and (3) Children's figured worlds of themselves. 
Overall counter narratives of refugee families and children present unheard stories that depict and reflect their strengths, agency and competence in accessing and participating in early childhood education services in the country of migration, while shedding light on their figured worlds, hence multiple dynamic identities they constructed. The process of figuring out multiple dynamic identities were enacted while families and children figure out identities in relation to both themselves and other actors in their lives.

Considering the entirety of the counter narratives in the (sub)categories, findings highlight in many ways the agency of refugee families and children, in particular, their practices of coping, recovery, resilience and competence as they pertain to education, along with searching for and creating educational resources. Children and families figured out and claimed multiple identities during these practices which were either carried from the past or are constructed at the present as they build a new life in Turkey. They attached an utmost value to education and were conscious of the importance of reaching out and benefiting from educational opportunities available in their communities. Children were able to demonstrate successful progress in many domains of development when enrolled in culturally and linguistically responsive school programs with high contextual sensitivity to families' expectations and values. Families took various initiatives with sustained agency in supporting educational experiences of their children, including but not limited to engaging in active family-school partnership and building a repertoire of resources on their own to supplement children's learning in school. Observing the remarkable academic and socioemotional progress of children in their classrooms as well as the families' active agency to enhance learning experiences of children, teachers seemed to engage in a process of re-shaping their perceptions towards working with refugee children and families. Thus, they perceived themselves more committed and dedicated to their profession.

We argue that such identities interwoven in counter narratives of Syrian families and children are counterintuitive and stand against the conventional and stereotypical perceptions of refugee identity. Hence, we believe that circulating counter narratives of refugee families and children and making them heard and visible across education research and in teacher education programs may provide a powerful tool to help eliminate the deficit model of refugee individuals that dominates and perpetuates the relevant discourse (Baker \& McEnery, 2005).

\section{Conclusion}

The study has implications for educational research and teacher education in Turkey as the country hosts the world's largest number of child refugee population in the world. The findings from the stories of refugee children and families' offer a rich potential for further research in terms utilizing strength-based approaches and drawing on counter-narratives as a methodological tool in exploring the experiences of refugee children and families. Such strength-based perspectives do not minimize struggles of refugee people, rather direct our attention to their potential as well as challenges and shift the center of the critical inquiries more to the structural barriers surrounding refugee individuals at national and international levels. Another implication highlights the importance of introducing counter narratives of Syrian families and children to pre-service and in-service teachers and encourage them to search for and share such stories. Considering the lack of courses in Turkey for preservice teachers, such as Multicultural Education and Inclusive Education, as well as limited professional development opportunities for in-service teachers, it is crucial to create alternative spaces so as to challenge the hegemonic deficit narratives of refugees in education. 